Avoimesti luettavissa osoitteessa http://journal.fi/ainedidaktiikka

ainedidaktiikka

\title{
Matematiikan parhaaksi osaajaksi kehittyminen perusopetuksen aikana
}

\author{
Laura Niemi ${ }^{1}$, Jari Metsämuuronen ${ }^{2}$, Markku Hannula ${ }^{1}$ ja Anu Laine ${ }^{1}$ \\ ${ }^{1}$ Kasvatustieteellinen tiedekunta, Helsingin yliopisto \\ ${ }^{2}$ Kansallinen koulutuksen arviointikeskus
}

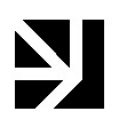

Tutkimus perustuu Opetushallituksen ja Kansallisen koulutuksen arviointikeskuksen hankkeessa tuotettuun pitkittäisaineistoon, jossa samaan ikäluokkaan kuuluvien oppilaiden matematiikan osaamisen kehitystä on seurattu vuosien 2005-2012 aikana perusopetuksen kolmannelta vuosiluokalta yhdeksännelle. Tutkimus kohdistuu matematiikan parhaisiin osaajiin ja siihen, miten heidän osaamisensa on kehittynyt perusopetuksen aikana ja mikä erottaa parhaat osaajat muista. Tutkimusaineisto käsittää yhteensä 2051 oppilasta, jotka ovat osallistuneet kolmannella, kuudennella ja yhdeksännellä vuosiluokalla pidettyihin matematiikan osaamista kartoittaviin kokeisiin. Parhaat osaajat on määritetty yhdeksännen vuosiluokan kokeessa menestymisen perusteella. Heitä on yhteensä 256 (12,5\%). Tutkimustulosten mukaan suurin osa parhaista osaajista erottuu muusta tutkimusjoukosta jo kolmannella vuosiluokalla, ja ero muihin oppilaisiin näkyy selkeästi kuudennella luokalla. Oppilaan aikaisempi osaaminen, käsitys omasta osaamisesta ja vanhempien koulutustaso olivat selkeitä parempaa osaamista selittäviä tekijöitä. Tutkimuksessa havaittiin, että parhaiden osaajien tasolle voi yltää myös keskitasoa heikommasta lähtötasosta.

Perusopetus, matematiikan oppimistulokset, parhaat osaajat, pitkittäistutkimus, kansallinen arviointi

Lähetetty: 28.6.2019

Hyväksytty: 20.12.2019

Vastuukirjoittaja: laura.niemi@helsinki.fi

DOI: $10.23988 /$ ad. 83384 


\section{Johdanto}

Suomalaislasten ja -nuorten matematiikan osaamisesta on jo pitkään oltu kiinnostuneita sekä kansallisella että kansainvälisellä tasolla. Suomalaisten oppilaiden matematiikan osaaminen on kansainvälisissä vertailuissa edelleen huipputasoa, vaikka sekä osaamistasossa että koulutuksellisen tasa-arvon toteutumisessa on tapahtunut viime vuosina heikentymistä. Osaamisessa on havaittavissa myös eriytymistä sukupuolen, sosioekonomisen taustan ja alueiden suhteen (mm. Vettenranta ym., 2016b). Myös erinomaiselle osaamistasolle yltävien oppilaiden määrä on viime vuosien aikana pienentynyt (Hiltunen \& Nissinen, 2018, s. 219).

Kansainvälisillä ja kansallisilla arvioinneilla on tärkeä merkitys koulutusjärjestelmän kehittämistyössä. Kansallisen arvioinnin tavoitteena on tuottaa tietoa suomalaiselle koulutusjärjestelmälle asetettujen tavoitteiden saavuttamisesta ja kehittää koulutusjärjestelmää tuotettujen tulosten pohjalta. Lisäksi koulutuksellisen tasa-arvon toteutuminen on yhtenä kiinnostuksen kohteena. Kansallisella arvioinnilla on tärkeä merkitys myös vertailtavuuden kannalta (Jakku-Sihvonen, 2013).

Tämä tutkimus pohjautuu kansallisesti laajaan ja merkittävään Opetushallituksen ja Kansallisen koulutuksen arviointikeskuksen (Karvi) tutkimusaineistoon, jossa samoja oppilaita on seurattu perusopetuksen kolmannelta vuosiluokalta toisen asteen koulutuksen loppuun neljällä eri mittauskerralla vuosien 2005-2015 aikana. Tutkimuksessa keskitytään tarkastelemaan kolmea ensimmäistä mittauskertaa (vuosina 2005, 2008 ja 2012) oppilaiden ollessa kolmannella, kuudennella ja yhdeksännellä vuosiluokalla.

Tutkimusaineistosta on laadittu eri mittauskertojen jälkeen useita eri tutkimusraportteja (mm. Huisman, 2006; Metsämuuronen, 2013, 2017; Metsämuuronen \& Salonen, 2017; Metsämuuronen \& Tuohilampi, 2017; Niemi \& Metsämuuronen, 2010; Rautopuro, 2013), ja aineistoa on tarkasteltu monesta eri näkökulmasta yleisellä tasolla. Tässä tutkimuksessa tarkastelun kohteena ovat matematiikan parhaat osaajat eli yhdeksännen vuosiluokan kansallisessa kokeessa parhaiten suoriutuneet oppilaat $(12,5 \%)$. Opinnoissaan hyvin menestyneisiin oppilaisiin tai heidän opintopolkuihinsa liittyvä tutkimustieto on erityisesti kansallisessa kontekstissa vähäistä. Tällainen tutkimus kuitenkin tuottaa arvokasta tietoa muun muassa siitä, mitä tekijöitä menestyksen taustalla on ja miten hyvää opintomenestystä voidaan edesauttaa ja tukea. Muun muassa vuoden 2015 PISA-tutkimus (Vettenranta ym., 2016b) osoittaa että matematiikassa parhaiten osaavien oppilaiden osuus on vähentynyt. Tutkimukset ovat osoittaneet, että hyvä matematiikan taito toimii pohjana tekniikan alojen ja luonnontieteiden opiskelulle ja on yhteydessä korkeampaan tulotasoon (mm. Blau, Ferber \& Winkler, 2010; Crawford \& Cribb, 2013). Perusopetus antaa valmiudet ja kelpoisuuden toisten asteen opintoihin ja sen myötä osaamisella ja valinnoilla on keskeinen merkitys elinkeinoelämälle (Pursiainen, Muukkonen, Rusanen \& Harmoinen, 2018). 


\section{Ainedidaktiikka 4(1) (2020)}

Tutkimuksen tarkoituksena on selvittää, millaisia muutoksia yhdeksännen vuosiluokan kokeessa parhaiten menestyneiden oppilaiden matematiikan osaamisessa on tapahtunut perusopetuksen aikana. Tavoitteena on selvittää, mikä erottaa parhaat osaajat muista ja mitkä tekijät selittävät erinomaista osaamista yhdeksännen vuosiluokan päättyessä, vaikka lähtötaso olisi ollut keskitasoa heikompaa. Aikaisemmat tulokset osoittavat, että matemaattisen osaamisen taso eriytyy jo varhaisina kouluvuosina ja erot ovat merkittävät perusopetuksen päättövaiheessa (Metsämuuronen \& Tuohilampi, 2017).

\section{Matematiikan osaamiseen yhteydessä olevia tekijöitä}

Opetussuunnitelma ohjaa koulutuksen toteutusta ja sen myötä oppimistuloksia. Oppilaan osaaminen ja siten myös matematiikan osaaminen voidaan määrittää opetussuunnitelman kautta. Oppilaan oppimistuloksia tarkastellaan suhteessa koulutusjärjestelmän tasolla asetettuihin tavoitteisiin.

Perusasetelmassa opetussuunnitelmaa tarkastellaan koulutusjärjestelmän tasolta kohti oppimistuloksia ylemmän tason vaikuttaessa aina yksityisempään tasoon. Perinteistä kolmitasoista kirjoitetun/tarkoitetun (intended curriculum), toimeenpannun (implemented curriculum) ja toteutuneen opetussuunnitelman (attained curriculum) mallia (Robitaille \& Garden, 1996) käytetään muun muassa IEA-järjestön arviointitutkimusten, kuten matematiikan ja luonnontieteiden osaamista mittaavien TIMSStutkimusten taustalla (mm. Mullis \& Martin, 2013; Vettenranta, Hiltunen, Nissinen, Puhakka \& Rautopuro, 2016a). Kansainvälisissä oppimistulostutkimuksissa tavoitteena on arvioida oppilaiden oppimistulosten tasoa ja laatua sekä selvittää tekijöitä, jotka ovat yhteydessä suorituksiin ja joihin voidaan vaikuttaa muun muassa opetussuunnitelmalla. Kuviossa 1 on esitetty malli, jossa koulutusjärjestelmää koskeva yhteiskunnallinen taso luo ytimen sille, millaisia oppimismahdollisuuksia oppilaille tarjotaan ja millaista opetusta kouluissa toteutetaan (toimeenpantu opetussuunnitelma). Oppilaan tiedot, taidot ja asenteet muodostuvat suhteessa opetussuunnitelman perusteisiin ja niiden pohjalta toteutettuun opetukseen paikallisella tasolla. 
Kuvio 1. Kolmitasoinen opetussuunnitelmamalli (Robitaillen \& Gardenin, 1996 mallia mukaillen).

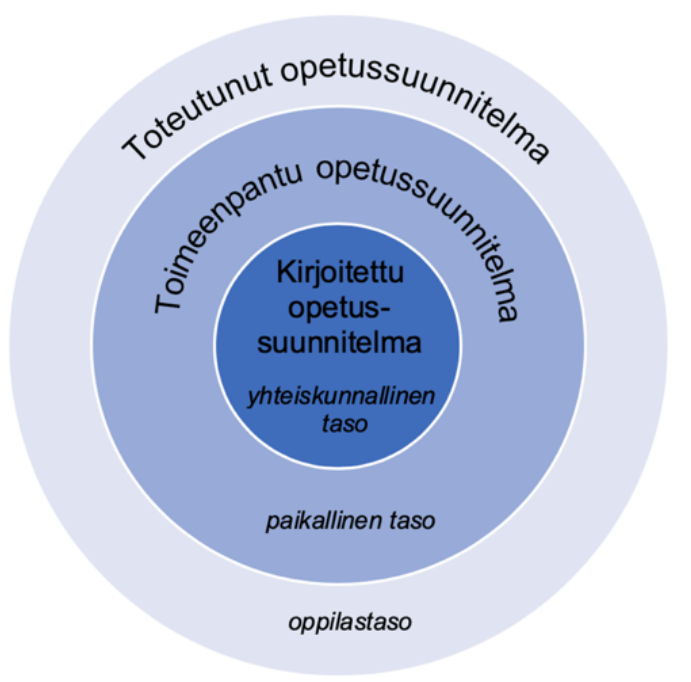

Matematiikan osaaminen kehittyy toimeenpannun ja toteutuneen opetussuunnitelman kautta, ja nämä perustuvat kansalliseen kirjoitettuun opetussuunnitelmaan. Matematiikan osaamisen tulisi opetussuunnitelmamallin mukaan tarkasteltuna vastata kirjoitetussa opetussuunnitelmassa asetettuja tavoitteita. Tässä tutkimuksessa käsitellään tarkemmin perusopetuksen opetussuunnitelman perusteita vuodelta 2004 (Opetushallitus, 2004), koska tutkimuksessa käytettävä arviointiaineisto pohjautuu kyseiseen opetussuunnitelmaan. Tämän jälkeen vuonna 2014 on annettu uudet opetussuunnitelman perusteet (Opetushallitus, 2014). Matematiikan tavoitteet ja sisällöt eivät ole kuitenkaan juuri muuttuneet uudemman opetussuunnitelman perusteiden osalta. Matematiikan osuus vuoden 2004 perusteissa jakautuu vuosiluokkien 1-2, 3-5 sekä 6-9 osioihin, joissa esitetään tavoitteet, keskeiset sisällöt ja kuvaukset oppilaan hyvästä osaamisesta 2. ja 5. vuosiluokkien päättyessä sekä 9. vuosiluokan kohdalla päättöarvioinnin kriteerit arvosanalle 8 .

Matematiikan keskeiset sisällöt vuosiluokkien 1-5 aikana ovat luvut ja laskutoimitukset, algebra, geometria sekä tietojen käsittely, tilastot ja todennäköisyys. Vuosiluokkien 6-9 osalta keskeiset sisällöt ovat ajattelun taidot ja menetelmät, luvut ja laskutoimitukset, algebra, funktiot, geometria, todennäköisyys ja tilastot (Opetushallitus, 2004, ss. 161-162, 164 165).

Oppilaan matematiikan arviointi niin opettajan antamana kuin kansallisen oppimistulosarvioinnin osaltakin perustuu opetussuunnitelman perusteissa määriteltyihin kuvauksiin oppilaan hyvästä osaamisesta ja päättöarvioinnin kriteereihin. Oppilaan hyvän osaamisen kuvaukset on laadittu 2. ja 5. vuosiluokan päätteeksi. Hyvän osaamisen kuvaukset ja päättöarvioinnin kriteerit määrittelevät kansallisesti tason arvosanalle 8 (Opetushallitus, 2004, s. 262). Hyvän osaamisen kuvauksiin ja päättöarvioinnin kriteereihin on listattu sisältöalueittain asioita, joita oppilaan tulisi osata saavuttaakseen hyvän osaamisen tason. Yhdeksännen vuosiluokan päätteeksi oppilaan tulisi esimerkiksi algebran sisältöalueelta osata 
ratkaista ensimmäisen asteen yhtälö tai geometrian sisältöalueelta osata soveltaa oppimiansa piirin, pinta-alan ja tilavuuden laskutapoja (ks. Opetushallitus, 2004, ss. 162-163, 165-166).

Toimeenpannun opetussuunnitelman lisäksi oppilaan matematiikan osaamiseen vaikuttavat muun muassa kotitausta ja yksilölliset ominaisuudet kuten asennoituminen ja kyvykkyys (Kupari \& Nissinen, 2015). Useat eri tutkimukset ovat osoittaneet, että oppilaan asenteiden ja koulusaavutusten välillä on merkittävä ja vuorovaikutuksellinen yhteys. Positiivinen asenne matematiikkaa kohtaan on yhteydessä sekä matematiikan osaamistasoon että toista astetta koskeviin valintoihin (Metsämuuronen, 2017). Jo Bloomin kouluoppimisen teorian (1976) mukaan oppilaan affektiivinen lähtötaso selitti jopa neljäsosan matematiikan testipistemäärien vaihtelusta. Myös uudemmat tutkimustulokset osoittavat samansuuntaisia tuloksia. Esimerkiksi Else-Questin, Hyden ja Linnin (2010) sekä Winhellerin, Hattien ja Brownin (2013) mukaan oppilaat, joiden asenteet matematiikkaa kohtaan ovat myönteisiä, suoriutuvat matematiikassa muita oppilaita paremmin. Toisaalta selityssuhde on nähtävissä myös toiseen suuntaan. Suomessa osaamisen ja asenteiden välinen yhteys nähdään enimmäkseen osaamisen määrittäessä matemaattista minäkuvaa $(\mathrm{mm}$. Williams \& Williams, 2010). Myös Opetushallituksen keräämään pitkittäisaineistoon liittyvä tutkimus osoittaa, että matematiikan osaaminen alakoulun aikana vaikuttaa matematiikka-asenteeseen vielä ylemmilläkin luokka-asteilla (Tuohilampi \& Hannula, 2013).

Matematiikkaan liittyvien asenteiden kartoittamisessa käytetään yleisesti Fenneman ja Shermanin (1976) luomaa asennetestiä. FennemaSherman -testiä käytetään useissa kansainvälisissä tutkimuksissa, muun muassa PISA- (OECD, 2013) ja TIMSS-tutkimuksissa (Mullis \& Martin, 2013). Lyhennetty versio Fennema-Sherman -testistä on ollut myös vakiotestinä kansallisissa matematiikan arviointitutkimuksissa vuodesta 1998 lähtien (Metsämuuronen, 2009). Opetushallituksen ja Karvin käyttämässä testistössä asennetta matematiikkaan kartoitetaan kolmesta näkökulmasta: käsitys itsestä matematiikan osaajana, matematiikasta pitäminen ja käsitys matematiikan hyödyllisyydestä. Kansallisissa arviointitutkimuksissa käytettävä mittari vastaa pitkälti kansainvälisissä tutkimuksissa käytettävää versiota. Kansallisessa versiossa kuitenkin käytetään kansainvälisestä versiosta poiketen 5-portaista Likert-asteikkoa 4-portaisen sijaan.

Sekä kansallisesti että kansainvälisesti (Kupari, Sulkunen, Vettenranta \& Nissinen, 2012) tarkasteltuna suomalaisoppilaiden asenteissa matematiikkaa kohtaan on havaittavissa heikentymistä. Karvin pitkittäistutkimuksen mukaan (Metsämuuronen, 2013) matematiikasta pitäminen laskee jo alakoulun aikana ja käsitys itsestä matematiikan osaajana laskee myöhemmin yläkoulun aikana.

Käsitys itsestä matematiikan osaajana on merkittävä osa-alue matematiikan osaamista ja oppimista tarkastellessa. Siihen liittyy tutkimuksissa yleisesti käytettyjä käsitteitä kuten minäpystyvyys (self-efficacy) (mm. Bandura, 1977; Schunk \& Richardson, 2011), itseluottamus (selfconfidence) (mm. Parsons, Croft \& Harrison, 2009) ja minäkuva (selfconcept) (mm. Goldman \& Penner, 2016). Myös käsitettä minäkäsitys pidetään näille rinnasteisena. Linnanmäen (2004) mukaan minäkäsitys 
sisältää näkemyksen omista kyvyistä, resursseista, asenteista ja tunteista sekä muotoutuu yksilön ja ympäristön välisessä vuorovaikutuksessa.

Käsityksen itsestä matematiikan osaajana on todettu useissa tutkimuksissa olevan sisäistä tai ulkoista motivaatiota selvemmin yhteydessä osaamiseen ja ennustavan parempaa koulumenestystä (mm. Bryan, Glynn \& Kittleson, 2011; Jiang, Song, Lee \& Bong, 2014). Hannula, Bofah, Tuohilampi ja Metsämuuronen (2014) ovat tutkineet osaamisen ja minäkuvan välistä suhdetta. Tutkimusaineistona on käytetty tämän tutkimuksen kanssa vastaavaa Karvin pitkittäisaineistoa kolmannelta vuosiluokalta yhdeksännelle. Tulosten mukaan osaamisen ja minäkuvan välinen suhde on selkeästi vuorovaikutteinen kuudennelta vuosiluokalta yhdeksännelle, ja kausaalisuhde on havaittavissa osaamisesta minäkuvaan kolmannelta vuosiluokalta kuudennelle.

Matematiikkaan liittyvissä asenteissa ja erityisesti minäkuvassa on nähtävissä edelleen eroa sukupuolten välillä, vaikka sukupuolierot matematiikan osaamisessa ovat tasoittuneet (Hirvonen, 2012). Tyttöjen heikompi minäkuva näkyy esimerkiksi lukion matematiikan pitkän ja lyhyen oppimäärän valinnassa sekä teknisille aloille hakeutumisessa (Hannula \& Holm, 2018). Lisäksi lukiokoulutuksen päättövaiheessa naisopiskelijat kokevat miesopiskelijoita enemmän negatiivisia tunnetiloja kaikissa taitotasoryhmissä (Metsämuuronen \& Tuohilampi, 2017, s. 67).

Minäkuvan ja motivaation lisäksi useat tutkimukset osoittavat, että oppilaan sosioekonomisella taustalla on vahva yhteys matematiikan osaamiseen koulussa (mm. Davis-Kean, 2005; Kupari, 2006; Marks, Cresswell \& Ainley, 2006). Suomessa sosioekonomisen taustan yhteys oppimistuloksiin on kuitenkin OECD-maiden pienimpiä (Kupari ym., 2013). Hotulainen ja muut (2016) ovat tutkineet metropolialueen nuorten siirtymää ja siihen liittyviä valintoja perusopetuksesta toiselle asteelle. Heidän mukaansa perheen sosioekonominen tausta ja erilaiset hyvinvointitekijät ennustavat osaamisen kehittymistä, koulumenestystä ja toisen asteen koulutusvalintaa. Sosioekonomisen taustan yhteys koulumenestykseen on havaittu muissakin tutkimuksissa. Pitkittäistutkimuksessa vanhempien lukiokoulutuksella havaittiin yhteys merkitsevästi parempaan matematiikan suoritukseen toisen asteen lopussa (Metsämuuronen, 2017). Kuuselan (2006) mukaan vanhempien suorittamalla ylioppilastutkinnolla on yhteys lasten opintomenestykseen. Lisäksi kodin antama tuki koulunkäynnille lisää osaamista (Metsämuuronen \& Tuohilampi, 2017).

\section{Parhaat osaajat matematiikassa}

Oppilaiden saavutuksia matematiikan osaamista mittaavissa kokeissa verrataan usein toisiinsa ja oppilaat luokitellaan osaamistason mukaan ryhmiin esimerkiksi heikot osaajat, keskitason osaajat ja parhaat osaajat. Tällöin parhaat osaajat määritellään usein keskitasoa paremmin menestyneiksi. Matematiikassa selvästi keskitasoa paremmin menestyvien oppilaiden osalla voidaan nähdä viittauksia myös matemaattiseen lahjakkuuteen (Renzulli \& Reis, 1985; Sheffield, 1994). Lahjakkuuden määrittely kuitenkin pelkkien koetulosten perusteella on mahdotonta (Snellman \& Räty, 1998). Matemaattiset taidot ovat kehitettävissä, kun taas matemaattinen 
lahjakkuus nähdään synnynnäisenä ominaisuutena (Leikin, 2014). Matemaattisesti hyvin menestyneistä oppilaista voidaan käyttää myös nimitystä matemaattisesti kyvykkäät oppilaat.

Matemaattista kyvykkyyttä voidaan tarkastella eri näkökulmista. Yleisesti matemaattinen kyvykkyys jaetaan koulukyvykkyyteen ja luovaan matemaattiseen kyvykkyyteen (Ruokamo, 2000). Koulukyvykkyydellä viitataan kyvykkyyteen, joka ilmenee lähinnä koulussa opiskeltaessa. Siihen liitetään nopea kyky hallita ja oppia matemaattista tietoa sekä käyttää sitä menestyksekkäästi. Koulukyvykkyyteen liittyy myös kyky suorittaa matemaattisia testejä. Luova matemaattinen kyvykkyys viittaa tieteelliseen matemaattiseen toimintaan liittyvään kyvykkyyteen, jonka tarkoituksena on tuottaa uusia ja merkittäviä tuloksia (Ruokamo, 2000, ss. 1819). Snellmanin ja Rädyn (1998) mukaan luovaa matemaattista kyvykkyyttä pidetään yleisesti matemaattisena lahjakkuutena ja koulukyvykkyyttä ahkeruutena. Koulukyvykkyys voidaan nähdä matemaattisen kyvykkyyden tai lahjakkuuden osa-alueena, jota pystytään mittaamaan erilaisin testein. Koulukyvykkyystasolle yltäminen ei kuitenkaan ole riittävä ehto matemaattiselle lahjakkuudelle.

Sheffieldin (1994) sekä Renzullin ja Reisin (1985) matemaattisten lahjakkuuden malleissa yhtenä lahjakkuuden osa-alueena nähdään ahkeruudenkin kautta saavutettava keskitasoa parempi kyvykkyys. Sheffieldin (1994) hierarkkisessa osaamisen mallissa koulukyvykkyydellä voi yltää jopa ongelman ratkaisijan tasolle, mutta ongelman asettajan ja luojan roolissa tarvitaan jo matemaattista lahjakkuutta. Renzullin ja Reisin (1985) mallissa lahjakkuus koostuu keskitason ylittävästä kyvykkyydestä (Above-Average Ability), opiskelumotivaatiosta (Task Commitment) ja luovuudesta (Creativity).

Oppilaan asenne opiskeluun on tärkeää. Muun muassa Kupiaisen (2016) mukaan merkittävimmät koulumenestystä ennustavat tekijät ovat oppilaan kehittyvä ajattelutaito ja halu käyttää sitä koulun odotusten suuntaisesti. Tämä nähdään yleisemmin motivaationa. Myös KeltikangasJärvisen (2007) mukaan koulumenestyksen tärkein selittäjä on motivaatio. Hänen mukaansa myös temperamentilla on yhteys koulumenestykseen. Vaikka temperamentti ei ole yhteydessä älykkyyteen, niin se on yhteydessä siihen, millä tavalla oppilas opiskelee. Motivaation ja temperamentin lisäksi Keltikangas-Järvisen (2007) mukaan minäkuvalla, itsetunnolla, elämänhallinnalla ja sosiaalisella asemalla luokkatovereiden joukossa on yhteys koulumenestykseen.

Hiltusen ja Nissisen (2018) mukaan matematiikassa parhaiten menestyneillä oppilailla on muita oppilaita korkeampi suoritusmotivaatio. Hiltunen ja Nissinen ovat tutkineet vuoden 2015 PISA-tutkimuksen matematiikassa parhaiten menestyneitä oppilaita. Heidän mukaansa matematiikassa parhaiten menestyneet oppilaat olivat muita oppilaita motivoituneempia menestymään PISA-kokeessa ja myös yleisesti suoritusmotivaatio oli heillä muita korkeampi.

Ahkeruus liitetään keskitasoa ylittävän kyvykkyyden saavuttamiseen. Ahkeruutta käsitellään tutkimuksissa eri termeillä, kuten sisukkuus ja sinnikkyys (mm. Tang, Wang, Guo \& Salmela-Aro, 2019; Duckworth 
\& Seligman, 2005). Tangin, Wangin, Guon ja Salmela-Aron (2019) pitkittäistutkimuksen mukaan ahkeruus ennustaa myöhempää koulumenestystä ja -innostusta. Tutkimuksessa havaittiin, että oppisisällön merkityksellisyys ei yksinään ennusta menestystä ja intoa vaan sen tulee yhdistyä oppilaan ahkeruuteen. Myös aikaisemmat tutkimukset (mm. Duckworth \& Seligman, 2005) osoittavat, että ahkeruudella ja itsesäätelyn taidoilla on keskeinen merkitys oppimisessa ja että nämä ennustavat akateemista menestystä älykkyysosamäärää enemmän. Myös kansallinen pitkittäistutkimus (Metsämuuronen, 2013) osoittaa, että yksi osaamista lisäävä tekijä yläkoulussa on tunnollinen koulutehtävien tekeminen. Asenne puolestaan vaikuttaa tunnolliseen työskentelyyn.

Sosioekonomisen taustan on nähty olevan yhteydessä parempaan opintomenestykseen. Muun muassa Hiltunen ja Nissinen (2018) osoittavat, että vuoden 2015 PISA-tutkimuksessa perheen korkea sosioekonominen tausta liittyi matematiikan erinomaiseen osaamiseen. Lisäksi Välijärvi (2017) on osoittanut, että sosioekonomisella taustalla on yhteys myös oppilaan suoritusmotivaatioon.

On pohdittu, millaiset opetusratkaisut tukevat parhaiden osaajien oppimista. Hiltusen ja Nissinen (2018, s. 231) mukaan hyvin pärjäävät oppilaat tarvitsevat tukea osaamisensa kehittämiseen ja motivaation ylläpitämiseen. Opetuksen eriyttämisen nähdään olevan toimiva keino kaikkien oppilaiden yksilöllisten tarpeiden huomioimiseen (Laine, 2010).

\section{Tutkimustehtävä}

Tutkimuksessa selvitetään, millaista matematiikassa parhaiten menestyneiden oppilaiden matematiikan osaaminen on perusopetuksen aikana ja miten osaaminen kehittyy. Lisäksi tutkimuksessa kartoitetaan, millaiset oppilaat kehittyvät matematiikan parhaiksi osaajiksi yhdeksännen vuosiluokan päättyessä. Tutkimuskysymykset ovat:

1. Miten yhdeksännen vuosiluokan matematiikan kokeessa parhaiten menestyneiden oppilaiden matematiikan osaaminen kehittyy perusopetuksen aikana?

2. Mitkä tekijät erottavat matematiikan parhaat osaajat muusta tutkimusjoukosta?

3. Millaiset kolmannen vuosiluokan matematiikassa heikosti menestyvät oppilaat kehittyvät yhdeksännen vuosiluokan parhaiksi osaajiksi?

\section{Tutkimusaineisto ja menetelmät}

Tutkimus pohjautuu Opetushallituksen ja Kansallisen koulutuksen arviointikeskuksen (Karvi) kansalliseen matematiikan osaamisen pitkittäisarviointiin. Pitkittäisarvioinnin aineistoissa samaan ikäluokkaan kuuluvia oppilaita on tutkittu neljällä eri mittauskerralla vuosien 2005-2015 aikana: toisen ja viidennen vuosiluokan päätyttyä, yhdeksännen vuosiluokan päättyessä sekä toisen asteen lopussa ammatillisessa koulutuksessa ja lukiossa. Tässä artikkelissa keskitytään kolmen ensimmäisen mittauskerran 
(vuosina 2005, 2008 ja 2012) analysointiin perusopetuksen osalta. Peruskoulun yhdeksännellä vuosiluokalla koko ikäluokka opiskelee vielä yhdessä, joten koulutusvalintojen ei vielä tässä vaiheessa pitäisi vaikuttaa opintoihin. Aineiston keräämisessä on käytetty huolellisesti toteutettua otantamenetelmää niin, että aineisto on kansallisesti edustava muun muassa maantieteellisesti, kielellisesti ja koulujen koon suhteen (Metsämuuronen, 2010).

Pitkittäisarvioinnissa on kartoitettu matematiikan osaamista sekä matematiikkaan liittyviä asenteita. Oppimistulosaineiston lisäksi oppilailta, opettajilta ja rehtoreilta on kaikkina vuosina kerätty tietoa muiden oppiaineiden, kuten äidinkielen osaamisesta, erilaisia taustatietoja sekä demografisia tietoja.

\section{Tutkimuskohde}

Tutkimusaineisto käsittää 4500 oppilasta, joista 2051 on osallistunut kaikkiin neljään eri mittauskertaan. Tässä tutkimuksessa keskitytään kolmeen ensimmäiseen mittauskertaan, jotka ovat olleet perusopetuksen aikana. Tästä joukosta tarkastellaan yhdeksännen vuosiluokan kokeessa parhaiten menestyneitä oppilaita. Oppilaat on jaettu kokeesta saatujen pistemäärien mukaan kymmeneen samankokoiseen ryhmään eli desiileihin, joista tarkastellaan kahta ylintä eli parhaiten menestyneiden oppilaiden ryhmää. Näiden oppilaiden osaaminen on koeosaamisen perusteella selvästi keskitasoa parempaa. Erityisen tarkastelun kohteena on ylimmän osaamistason desiili eli 10. desiili, josta käytetään nimitystä parhaat osaajat. Toiseksi ylimpään eli 9. desiiliin kuuluvista oppilaista käytetään nimitystä hyvät osaajat. Taulukossa 1 nähdään parhaiden ja hyvien osaajien sekä koko otokseen kuuluvien oppilaiden yhdeksännen vuosiluokan kokeesta saatujen pistemäärien eroja.

Taulukko 1. Koepisteet yhdeksännellä vuosiluokalla.

\begin{tabular}{|c|c|c|c|}
\hline koepisteet & $\begin{array}{l}\text { parjaat osaajat } \\
(n=256)\end{array}$ & $\begin{array}{l}\text { hyvät osaajat } \\
(\mathrm{n}=\mathbf{2 2 6})\end{array}$ & $\begin{array}{l}\text { koko otos } \\
(\mathrm{n}=\mathbf{2 0 5 1})\end{array}$ \\
\hline keskiarvo & 712,5 & 627,3 & 529,2 \\
\hline $\min$. & 654,2 & 602,8 & 131,0 \\
\hline $\max$. & 1029,5 & 649,3 & 1029,5 \\
\hline keskihajonta & 55,3 & 14,7 & 106,9 \\
\hline
\end{tabular}

Hyviä ja parhaita osaajia yhdeksännen vuosiluokan kokeessa menestymisen perusteella on yhteensä 482 (23,5\% koko otoksesta). Parhaita osaajia näistä on $256(12,5 \%$ koko otoksesta), joista poikia on $154(60,2 \%)$ ja tyttöjä 102 (39,8 \%). Taulukkoon 2 on koottu parhaiden ja hyvien osaajien sekä koko otokseen kuuluvien oppilaiden taustatietoja. 
Taulukko 2. Tutkimusjoukon taustatietoja.

\begin{tabular}{lllll} 
& & $\begin{array}{l}\text { parhaat } \\
\text { osaajat } \\
(\mathbf{n = 2 5 6}\end{array}$ & $\begin{array}{l}\text { hyvät osaajat } \\
(\mathbf{n = 2 2 6})\end{array}$ & $\begin{array}{l}\text { koko otos } \\
(\mathbf{n}=\mathbf{2 0 5 1})\end{array}$ \\
\hline sukupuoli & tyttö & $39,8 \%$ & $43,4 \%$ & $49,2 \%$ \\
& poika & $60,2 \%$ & $56,6 \%$ & $50,8 \%$ \\
kieliryhmä & suomi & $90,6 \%$ & $87,2 \%$ & $87,7 \%$ \\
& ruotsi & $9,4 \%$ & $12,8 \%$ & $12,3 \%$ \\
kotikieli & suomi & $89,8 \%$ & $88,1 \%$ & $86,7 \%$ \\
& ruotsi & $4,7 \%$ & $8,0 \%$ & $7,7 \%$ \\
& suomi ja ruotsi & $3,5 \%$ & $3,5 \%$ & $3,5 \%$ \\
suomi toisena $\%$ & jokin muu & $2,0 \%$ & $0,4 \%$ & $2,2 \%$ \\
kielenä & kyllä & $10,2 \%$ & $12,8 \%$ & $15,5 \%$ \\
-opetus & ei & $89,8 \%$ & $87,2 \%$ & $84,5 \%$ \\
kuntaryhmä & kaupunki & $63,7 \%$ & $56,6 \%$ & $54,7 \%$ \\
& taajama & $16,0 \%$ & $21,2 \%$ & $21,6 \%$ \\
lääni & maaseutu & $20,3 \%$ & $22,2 \%$ & $23,7 \%$ \\
& Etelä-Suomi $\%$ & $35,5 \%$ & $30,0 \%$ & $31,2 \%$ \\
& Länsi-Suomi & $34,4 \%$ & $38,1 \%$ & $42,0 \%$ \\
& Itä-Suomi & $19,9 \%$ & $17,3 \%$ & $12,9 \%$ \\
& Oulu & $8,2 \%$ & $9,7 \%$ & $9,2 \%$ \\
& Lappi & $2,0 \%$ & $4,9 \%$ & $4,7 \%$
\end{tabular}

\section{Matematiikan koetehtävät tutkimuksessa}

Kansallisissa arvioinneissa matematiikan oppimistuloksia mittaavien kokeiden tehtävät, arvosteluperusteet ja pisteytysohjeet laaditaan yleisesti asiantuntijaryhmissä. Lisäksi tehtäväsarjojen laadun arvioinnissa käytetään asiantuntijoita ja esitestausta. Tehtäväsarjoihin luodaan vaikeustasoltaan helppoja, keskivaikeita ja vaikeita osioita (Metsämuuronen, 2009). Sisältöalueet on valittu perusopetuksen opetussuunnitelman perusteiden (Opetushallitus, 2004) mukaisesti. Matematiikan koetehtävät mittaavat opetussuunnitelman toteutumista.

Arviointi kohdistuu matematiikan kokonaisosaamiseen, joka koostuu koko pitkittäisaineiston osalta kolmesta osa-alueesta: 1) luvut, laskutoimitukset ja algebra, 2) geometria ja 3) tietojen käsittely ja tilastot sekä todennäköisyys. Kolmannen vuosiluokan alussa suoritetun matematiikan arvioinnin tehtävät kohdistuivat lukujen ja laskutoimitusten, algebran sekä geometrian ja mittaamisen osa-alueisiin. Huismanin (2006) analysoinnissa tehtävät jaettiin sanallisiin ja mekaanisiin tehtäviin sekä peruslaskutoimituksiin ja ongelmanratkaisutehtäviin. Yhtenä ryhmänä olivat myös ratkaisujen perustelut.

Kuudennen vuosiluokan alussa matematiikan arviointi kohdistui lukujen ja laskutoimitusten, algebran sekä geometrian lisäksi myös tietojen käsittelyyn ja tilastojen sekä todennäköisyyden mittaamiseen. Matematiikan koe koostui päässälasku-, monivalinta- ja tuottamistehtävistä. Tehtävien valinnassa käytettiin aikaisemmissa matematiikan oppimistulosarvioinneissa olleita tehtäväosioita, joista valittiin vaikeustasoltaan ja erottelukyvyiltään soveltuvimmat. (Niemi, 2008, ss. 18-19.) 
Yhdeksännellä vuosiluokalla tehtävät ryhmiteltiin opetussuunnitelman (2004) mukaisiin sisältöalueisiin: algebra, funktiot, luvut ja laskutoimitukset sekä tilastot ja todennäköisyys. Tehtävät jakaantuivat päässälasku-, monivalinta- ja ongelmanratkaisutehtäviin. (Hirvonen, 2012, ss. 25-29.)

Eri luokka-asteilla käytetyt mittarit ovat olleet erilaisia. Oppimistulokset on kuitenkin vertaistettu eli saatettu yhteismitallisiksi osio-vasteteoriaan (Item Response Theory) perustuvan IRT-mallinnuksen avulla, mikä toimii lähtökohtana aineiston analyysille (ks. Metsämuuronen, 2009, s. 22-23). Kokeissa on ollut identtisiä linkkitehtäviä, joiden avulla kokeiden pistemäärät on saatu vastaamaan toisiaan. Linkkitehtävistä neljä pidettiin mukana kaikissa kolmessa kokeessa kolmannelta yhdeksännelle. Kolmannen ja kuudennen luokan välillä linkkitehtäviä oli seitsemän ja kuudennen ja yhdeksännen vuosiluokan välillä kymmenen. Linkkitehtävistä seitsemän oli lukujen ja laskutoimitusten ja algebran osa-alueelta, kaksi geometrian osa-alueilta ja neljä tietojenkäsittelyn ja tilastojen sekä todennäköisyyden osa-alueelta. (Metsämuuronen, 2013, ss. 41-42.)

Tutkimuksessa osaamista kuvaavat pisteet esitetään samalla asteikolla kuin PISA- ja TIMSS-tutkimuksissa, koska kokeiden standardipisteillä kolmannen ja yhdeksännen vuosiluokan osaamistasojen eroja ei saada näkyviin. Kokeen standardipisteet on muunnettu niin, että 9. vuosiluokalla osaamiseltaan keskitason oppilas saa 500 pistettä ja keskihajonta on 100 pistettä (Metsämuuronen, 2017, ss. 214-215). Tutkimusaineistossa heikoin suoritus oli 131 pistettä ja paras suoritus 1029,5 pistettä. Keskihajonta oli 106,89. Pitkittäisaineistosta ja sen mittareita koskevista teknisistä ominaisuuksia, kuten kokeen osa-alueiden reliabiliteettikertoimista, löytyy lisätietoa Metsämuurosen (2009) pitkittäisaineiston menetelmäratkaisuja käsittelevästä julkaisusta.

\section{Asenteiden kartoittaminen}

Opetushallitus kerää kansallisissa arvioinneissa osaamisen lisäksi tietoa oppilaiden asenteista. Asenteiden kartoittamiseen käytetään 15 osion Likert-asteikollista mittaria, joka pohjautuu laajalti käytettyyn Fenneman ja Shermanin (1976) matematiikka-asennemittariin. Asenteita kartoitetaan kolmesta näkökulmasta eri väittämin: minä osaajana (esim. Pystyn selviytymään vaikeistakin matematiikan tehtävistä.), käsitys oppiaineen hyödyllisyydestä (esim. Tulevissa opinnoissani tarvitsen matematiikan tietoja ja taitoja.) ja oppiaineesta pitäminen (esim. Opiskelen mielelläni matematiikkaa.) (Metsämuuronen, 2009, ss. 20-21).

Kolmannen vuosiluokan mittauksessa käytettiin lyhennettyä versiota standardimittarista niin, että oppiaineen hyödylliseksi kokemisen osa-alue jätettiin arvioinnin ulkopuolelle, koska kysymykset viittasivat pitkälti jatko-opintoihin ja työelämään. Lisäksi jäljelle jäävien osioiden sanamuotoja muokattiin konkreettisimmiksi. Kolme osiota olivat identtisiä. Myös Likert-asteikko oli erilainen kolmannella luokalla verrattuna kuudennen ja yhdeksännen vuosiluokan asteikkoon. Kolmannella vuosiluokalla käytettiin neliportaista Likert-asteikkoa viisiasteikkoisen sijaan. Pitkittäisaineistossa summapistemäärät muutettiin suhteelliseksi osuudeksi kokonaispistemäärästä, jotta tulokset ovat vertailukelpoisia (Metsämuuronen, 2013, ss. 47-48). 


\section{Tutkimusasetelma ja -menetelmät}

Tutkimusasetelma muodostui useammasta vertailukerrasta, jossa samoja henkilöitä mitattiin useaan kertaan ja he muodostivat itselleen henkilökohtaisen niin sanotun kontrolliryhmän (ks. Metsämuuronen, 2013, s. 33).

Tässä tutkimuksessa aineiston analysoinnissa käytettiin pääosin parametrisia tilastomenetelmiä. Tulosten kuvailussa käytettiin frekvenssija prosenttijakaumia sekä keski- ja hajontalukuja. Aineiston analysointi pohjautui pitkälti keskiarvojen vertailuun ja regressioanalyysin käyttöön. Ryhmien keskiarvojen väliseen vertailuun käytettiin t-testin ja varianssianalyysin eri muotoja, joiden avulla verrattiin ryhmien välisiä keskiarvoja toisiinsa huomioiden keskiarvoihin liittyvä virhe. T-testiä käytettiin kahden keskiarvon vertailuun ja varianssianalyysin käytössä vertailua laajennettiin useamman keskiarvon vertailuun, jossa käytettiin yhtä tai useampaa ryhmittelevää muuttuja selitettävälle muuttujalle (Metsämuuronen, 2003, s. 644). Efektikoon mittana käytettiin Cohenin $f$ - ja $d$-arvoja. Cohenin $f$ ilmaisee varianssianalyysin yhteydessä keskiarvojen välisen suuruuden. Efektikoko on pieni Cohenin $f$-arvon ollessa 0,10 , kohtuullinen arvon ollessa 0,25 ja suuri, kun arvo on suurempi kuin 0,40. Parittaisen t-testin yhteydessä efektikoon mittana käytettiin Cohenin $d$-arvoa, jossa arvo 0,20 kertoo vaikutuksen olevan pieni, arvo 0,50 vaikutuksen olevan keskisuuri ja arvo 0,80 on suuren efektikoon mitta. (Cohen, 1988; Metsämuuronen, 2003.)

Regressioanalyysin avulla pyrittiin löytämään, mitkä tekijät selittävät tutkittavan muuttujan vaihtelua. Kun regressioanalyysissa on useita selittäviä muuttujia, multippelikertoimen neliö $R^{2}$ kertoo, kuinka paljon muuttujien joukko kokonaisuutena selittää selitettävän muuttujan vaihtelua (Metsämuuronen, 2003, s. 577). Selvitettäessä, mikä erottaa parhaat osaajat muista selitettävänä muuttujana oli kaksiluokkainen muuttuja. Osin myös selittävät muuttujat esimerkiksi matematiikan ja äidinkielen osaamistasojen osalta on dikotomisoitu eli alkuperäinen muuttuja on jaettu kahteen ryhmään, jotta tulosten tulkinta on helpompaa. Tässä tapauksessa käytettiin logistista regressioanalyysia. Regressioanalyysien tulokset on koottu taulukoihin, joissa esitetään malliin vaikuttavien muuttujien regressiokertoimet $(B)$, keskivirheet, riskitasot $(\operatorname{Exp}(B))$ ja tilastolliset merkitsevyysarvot ( $p$-arvo). Riskitason, $\operatorname{Exp}(\mathrm{B})$, arvo on kerroin, joka osoittaa riskitason kuulua tutkittavaan ryhmään selittävän muuttujan kasvaessa yhden yksikön verran. Regressiokerroin (B) kertoo, kuinka voimakas yhteys selittävällä muuttujalla on selitettävään muuttujaan. Positiivinen kerroin merkitsee kasvavaa riskiä ja negatiivinen arvo riskin vähenemistä. (Jokivuori \& Hietala, 2007, ss. 70-72.)

\section{Tulokset}

Tulokset esitetään kuvailemalla ensin yhdeksännen vuosiluokan kokeessa parhaiten menestyneiden oppilaiden osaamisen tasoa kolmannella ja kuudennella vuosiluokalla. Vertailuryhmänä on hyvät osaajat eli oppilaat, joiden osaaminen on ollut yhdeksännen vuosiluokan kokeen perusteella 9. desiilin mukaista. Sen jälkeen tarkastellaan osaamisessa tapahtuneita muutoksia kolmannelta kuudennelle, kuudennelta yhdeksännelle ja kolmannelta yhdeksännelle vuosiluokalle. Lopuksi analysoidaan tekijöitä, 
jotka selittävät osaamisessa tapahtuneita muutoksia ja sitä, mikä erottaa parhaat osaajat muista oppilaista.

\section{Parhaiden ja hyvien osaajien taso kolmannella vuosiluokalla}

Kolmannella vuosiluokalla parhaiden osaajien joukossa alin kokeesta saatu pistemäärä oli 156,1 pistettä ja ylin 646,2 pistettä. Pisteiden keskiarvo oli 402,1 pistettä ja keskihajonta 82,2 pistettä. Vastaavasti hyvillä osaajilla alin kokeesta saatu pistemäärä oli 156,1 pistettä ja ylin 561,2 pistettä. Hyvien osaajien pisteiden keskiarvo oli 347,4 pistettä ja keskihajonta 74,2 pistettä. Kuviossa 2 ja taulukossa 3 on kuvattu, millaista tutkimusaineiston hyvien ja parhaiden osaajien osaaminen on ollut kolmannella vuosiluokalla. Niistä nähdään, että suurin osa tutkimusaineiston parhaista osaajista sijoittuu ylimpiin desiileihin ja hyvien osaajien sijoittuminen eri desiileihin on tasaisempaa. Parhaista osaajista useimmat erottuvat jo kolmannella vuosiluokalla muusta tutkimusjoukosta. Heistä lähes 40 prosenttia sijoittuu jo kolmannella vuosiluokalla ylimpään osaamistasoa kuvaavaan desiiliin ja 63,5 prosenttia kahteen ylimpään. Kuviosta 2 ja taulukosta 3 kuitenkin havaitaan, että myös alemmilta desiilitasoilta on noustu parhaiden osaajien joukkoon. Parhaiden osaajien ero kolmannella vuosiluokalla on muiden osaajien osaamistasoon verrattuna t-testin mukaan tilastollisesti erittäin merkitsevä $(t=-21,1 ; d f=313,9$; Cohenin $d=1,41 ; p<0,001 ; 95 \% C l[-137,65 ;-114,16])$.

Kuvio 2. Parhaiden ja hyvien osaajien sijoittuminen osaamista kuvaaviin desiileihin 3. vuosiluokalla.
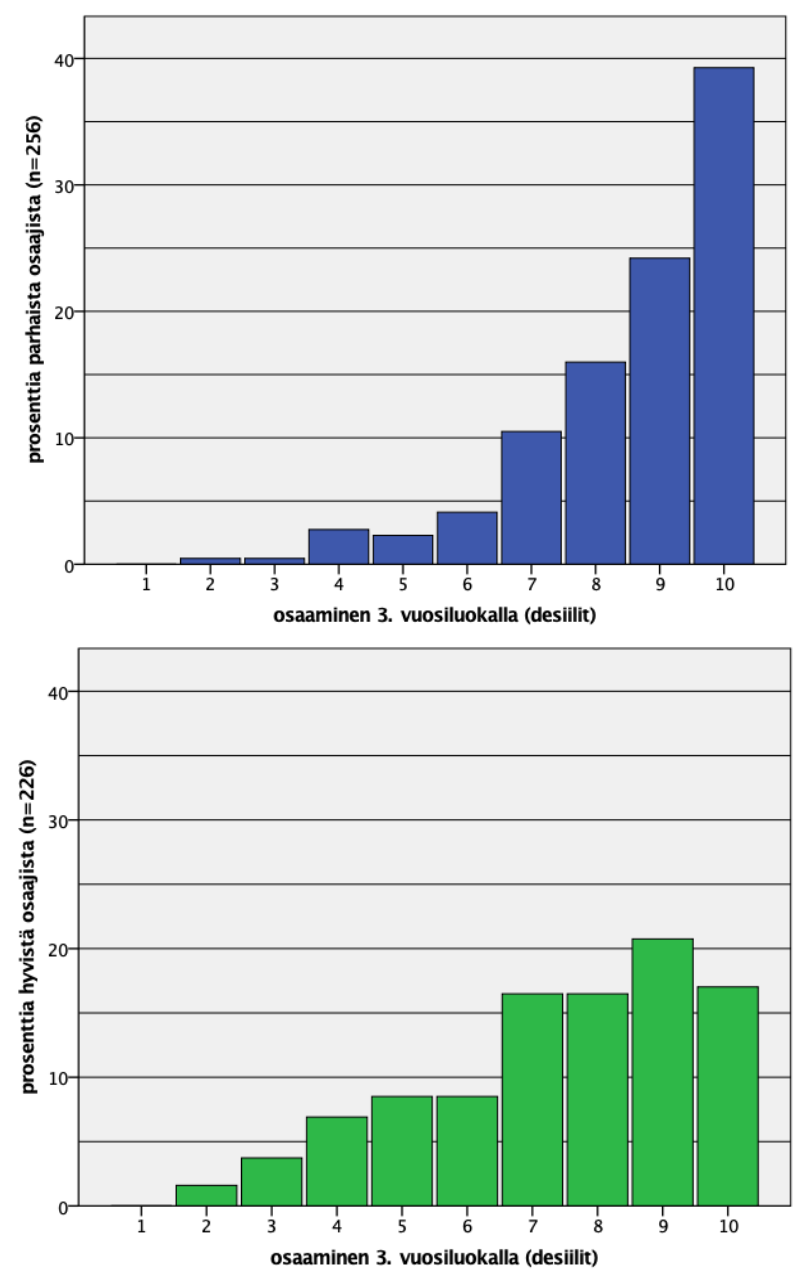
Taulukko 3. Tutkimusjoukon sijoittuminen osaamista kuvaaviin desiileihin 3. vuosiluokalla.

\begin{tabular}{llll} 
desiili & $\begin{array}{l}\text { parhaat osaajat } \\
(\mathbf{n = 2 5 6})\end{array}$ & $\begin{array}{l}\text { hyvät osaajat } \\
(\mathbf{n = 2 2 6})\end{array}$ & $\begin{array}{l}\text { koko otos } \\
(\mathbf{n}=\mathbf{2 0 5 1})\end{array}$ \\
\hline $\mathbf{1}$ & $0,0 \%$ & $0,0 \%$ & $10,8 \%$ \\
$\mathbf{2}$ & $0,5 \%(1$ oppilas $)$ & $1,6 \%$ & $12,0 \%$ \\
$\mathbf{3}$ & $0,5 \%$ & $3,7 \%$ & $11,1 \%$ \\
$\mathbf{4}$ & $2,7 \%$ & $6,9 \%$ & $14,8 \%$ \\
$\mathbf{5}$ & $2,3 \%$ & $8,5 \%$ & $11,7 \%$ \\
$\mathbf{6}$ & $4,1 \%$ & $8,5 \%$ & $6,5 \%$ \\
$\mathbf{7}$ & $10,5 \%$ & $16,5 \%$ & $10,7 \%$ \\
$\mathbf{8}$ & $16,0 \%$ & $16,5 \%$ & $8,6 \%$ \\
$\mathbf{9}$ & $24,2 \%$ & $20,7 \%$ & $9,5 \%$ \\
$\mathbf{1 0}$ & $39,3 \%$ & $17,0 \%$ & $4,2 \%$
\end{tabular}

\section{Parhaiden ja hyvien osaajien taso kuudennella vuosiluokalla}

Kuudennella vuosiluokalla parhaiden osaajien joukossa alin kokeesta saatu pistemäärä oli 399,1 pistettä ja ylin 835,5 pistettä. Pisteiden keskiarvo oli 581,5 pistettä ja keskihajonta 72,5 pistettä. Vastaavasti hyvillä osaajilla alin kokeesta saatu pistemäärä oli 350,2 pistettä ja ylin 694,1 pistettä. Hyvien osaajien pisteiden keskiarvo oli 522,7 pistettä ja keskihajonta 52,8 pistettä. Kuviosta 3 ja taulukosta 4 havaitaan, että tutkimusjoukon parhaat osaajat olivat muutamaa poikkeusta lukuun ottamatta selvästi keskitasoa parempia kuudennella vuosiluokalla. Myös hyvien osaajien taso alkaa määräytyä. Kuudennella vuosiluokalla parhaista osaajista 64,1 \% sijoittuu ylimpään osaamistasoa kuvaavaan desiiliin ja hyvistä osaajista puolet kahteen ylimpään desiiliin. Tutkimusjoukosta löytyy kuitenkin oppilaita, joiden osaaminen on kasvanut kuudennelta vuosiluokalta keskitasosta tai sitä heikommasta osaamistasosta ylimmälle, vaikka sijoittuminen desiileihin 3-7 onkin hyvin vähäistä $(5,7 \%)$. Hyvistä osaajista jopa 27,2 prosenttia on ollut osaamistasoltaan keskitasoa tai sitä heikompaa (desiilit 2-7) kuudennella vuosiluokalla. 
Ainedidaktiikka 4(1) (2020)

Kuvio 3. Parhaiden ja hyvien osaajien sijoittuminen osaamista kuvaaviin desiileihin 6. vuosiluokalla.
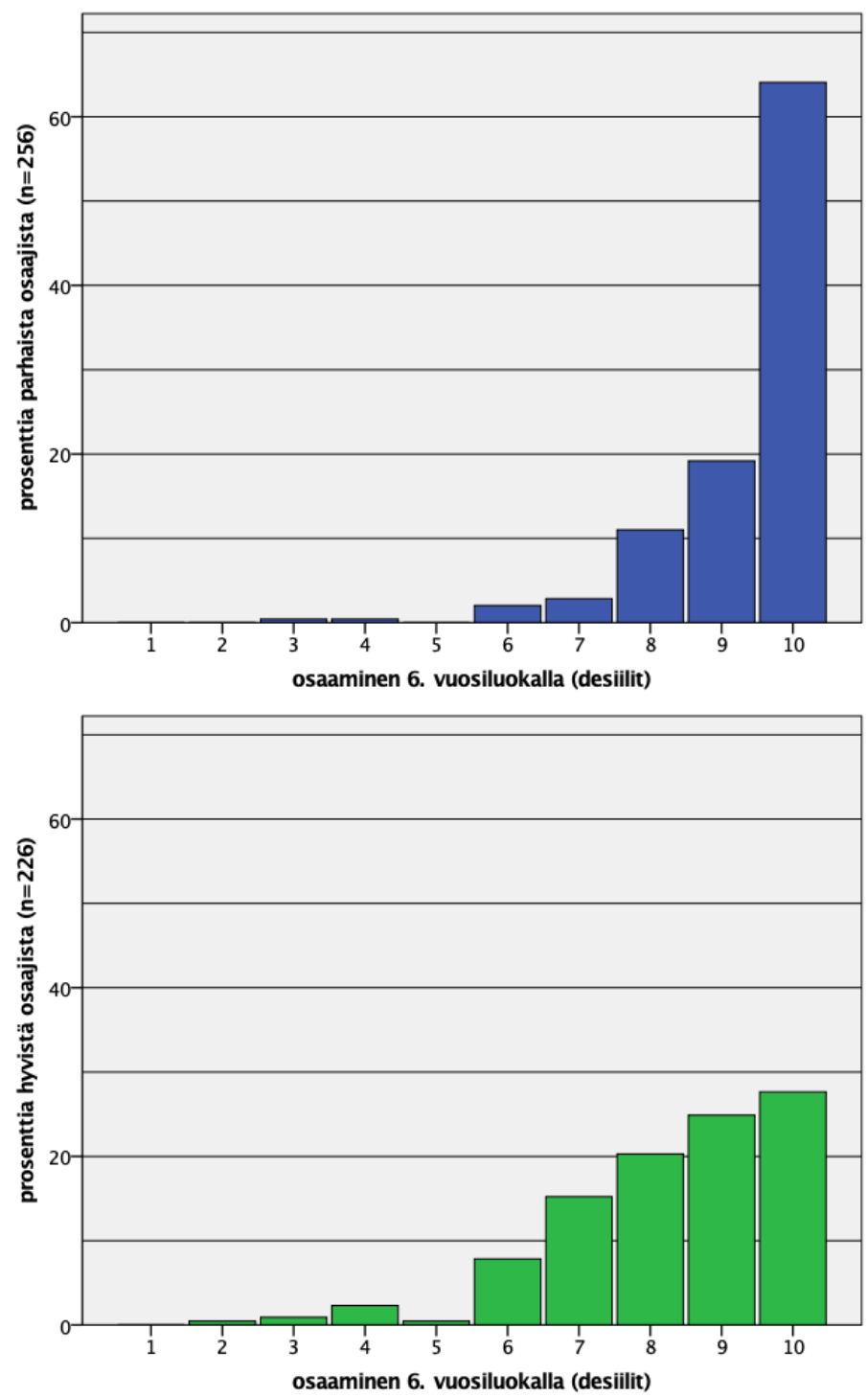

Taulukko 4. Tutkimusjoukon sijoittuminen osaamista kuvaaviin desiileihin 6. vuosiluokalla.

\begin{tabular}{llll} 
desiilit & $\begin{array}{l}\text { parhaat osaajat } \\
(\mathbf{n = 2 5 6 )}\end{array}$ & $\begin{array}{l}\text { hyvät osaajat } \\
(\mathbf{n = 2 2 6})\end{array}$ & $\begin{array}{l}\text { koko otos } \\
(\mathbf{n = 2 0 5 1 )}\end{array}$ \\
\hline $\mathbf{1}$ & $0,0 \%$ & $0,0 \%$ & $10,0 \%$ \\
$\mathbf{2}$ & $0,0 \%$ & $0,5 \%$ & $10,3 \%$ \\
$\mathbf{3}$ & $0,4 \%$ & $0,9 \%$ & $12,4 \%$ \\
$\mathbf{4}$ & $0,4 \%$ & $2,3 \%$ & $15,4 \%$ \\
$\mathbf{5}$ & $0,0 \%$ & $0,5 \%$ & $10,4 \%$ \\
$\mathbf{6}$ & $2,0 \%$ & $7,8 \%$ & $11,8 \%$ \\
$\mathbf{7}$ & $2,9 \%$ & $15,2 \%$ & $11,5 \%$ \\
$\mathbf{8}$ & $11,0 \%$ & $20,3 \%$ & $9,0 \%$ \\
$\mathbf{9}$ & $19,2 \%$ & $24,9 \%$ & $6,6 \%$
\end{tabular}




\section{Parhaiden osaajien osaamisen muutos}

Parhaiden osaajien osaamisessa tapahtunutta muutosta perusopetuksen aikana on havainnollistettu kuviossa 4. Osaamisen muutokset on kuvattu kuvion ensimmäisessä osassa kolmannelta vuosiluokalta kuudennelle, toisessa osassa kuudennelta vuosiluokalta yhdeksännelle ja kolmannessa osassa kolmannelta vuosiluokalta yhdeksännelle.

Kuvio 4. Parhaiden osaajien osaamisen muutos kolmannelta vuosiluokalta kuudennelle, kuudennelta vuosiluokalta yhdeksännelle ja kolmannelta vuosiluokalta yhdeksännelle.
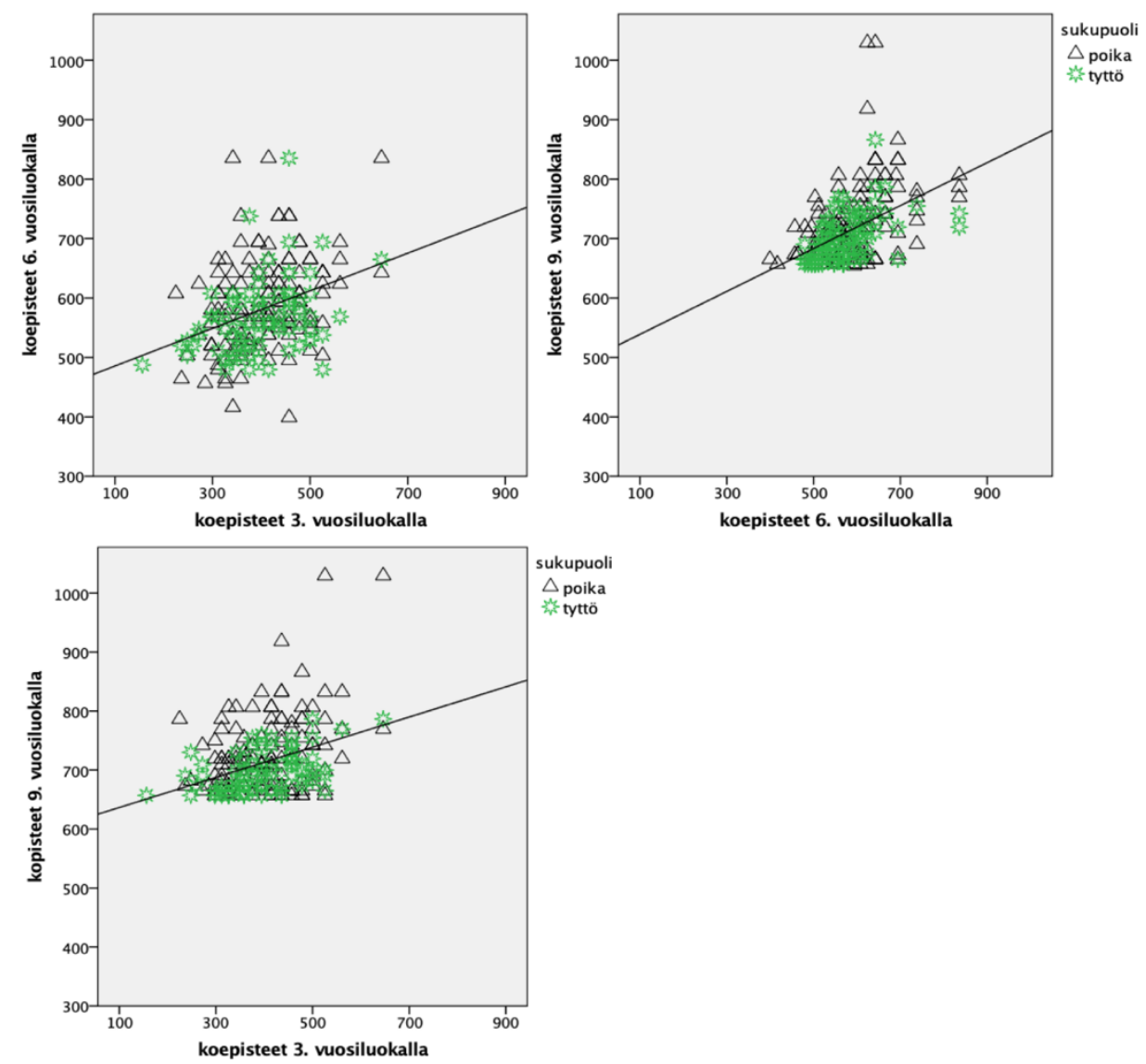

Parhaiden osaajien osaamisen keskimääräinen muutos kolmannelta vuosiluokalta kuudennelle on 179,4 pistettä $(+44,6 \%)$. Pojilla osaaminen on kasvanut 183,6 pisteellä $(45,4 \%)$ ja tytöillä 172,9 pisteellä $(43,5 \%)$. Kolmannen vuosiluokan osaamisen selitysosuus kuudennen vuosiluokan osaamisen vaihtelusta on 12 prosenttia (selitysaste $R^{2}=0,12$ ). Lähtötaso kolmannella vuosiluokalla on ollut vaihtelevaa eikä osaamisen muutoksissa näy eroja tyttöjen ja poikien välillä.

Parhailla osaajilla osaamisen muutos kuudennelta vuosiluokalta yhdeksännelle on keskimäärin 131,0 pistettä (+22,5\%). Pojilla osaaminen on kasvanut 133,1 pisteellä $(22,6 \%)$ ja tytöillä 128,5 pisteellä $(22,5 \%)$. Kuudennen vuosiluokan osaamisen selitysosuus yhdeksännen vuosiluokan osaamisen vaihtelusta on 22 prosenttia (selitysaste $R^{2}=0,22$ ). Kuviosta 4 havaitaan, että tyttöjen osaamistason muutos on poikia tasaisempaa kuudennen ja yhdeksännen vuosiluokan välillä. Tyttöjen koepisteet asettuvat tiiviisti kuviossa samaan ryppääseen, kun taas poikien pisteet alkavat 
hajautua enemmän. Kuvion oikeassa reunassa havaitaan oppilaat, joiden osaamisessa ei ole juurikaan tapahtunut muutosta vaan he ovat saavuttaneet osaamistasoltaan korkean pistemäärän jo kuudennella vuosiluokalla. Yläreunassa näkyy muutama yksittäinen poika, joiden osaamisessa koepisteet yhdeksännellä vuosiluokalla ovat erittäin korkeat samalla kun osaamisen kasvu kuudennen vuosiluokan koepisteisiin suhteutettuna on myös suuri.

Parhaiden osaajien osaamisen muutos kolmannelta vuosiluokalta yhdeksännelle on keskimäärin yhteensä 310,4 pistettä (+77,2 \%). Pojilla osaaminen on kasvanut 316,7 pisteellä $(78,2 \%)$ ja tytöillä 301,4 pisteellä $(75,8 \%)$. Kolmannen vuosiluokan osaamisen selitysosuus yhdeksännen vuosiluokan osaamisen vaihtelusta on 13 prosenttia (selitysaste $R^{2}=0,13$ ). Kuviosta havaitaan, että pojat hallitsevat korkeimpia pistemääriä yhdeksännellä vuosiluokalla. Vasemmassa reunassa nähdään oppilaat, joiden osaamistaso on ollut kolmannella vuosiluokalla keskitasoa heikompaa, mutta jotka ovat kuitenkin saavuttaneet parhaiden osaajien tason yhdeksännellä vuosiluokalla.

Parhaiden osaajien osaaminen kolmannelta yhdeksännelle vuosiluokalle on selkeästi lisääntynyt. Tämä voidaan varmistaa toistettujen mittausten varianssianalyysillä, jonka mukaan kolmen mittauskerran välillä on tilastollisesti merkitsevä ero ja keskiarvojen välinen ero on suuri $(F=679,225 ; p=<0,001$; Cohenin $f=1,29)$. Lisäksi mittauskertojen välillä on lineaarinen yhteys $(F=1256,021 ; p=<0,001$; Cohenin $f=1,76)$ eli mittauskertojen välillä on riippuvuus. Lisäksi parhaat osaajat erottuvat muusta tutkimusjoukosta tilastollisesti erittäin merkitsevästi ja keskiarvojen välinen ero on suuri $(F=8056,163 ; p=<0,001$; Cohenin $f=4,45)$. Myös parittaisen t-testin (taulukko 5) mukaan osaaminen on lisääntynyt huomattavasti peruskoulun aikana. Keskiarvojen erot ovat suuria ja tilastollisesti erittäin merkitseviä.

Taulukko 5. Mittauskertojen parittaisen t-testin tulokset.

\begin{tabular}{|c|c|c|c|c|c|}
\hline mittauskerrat & $t$ & $d f$ & $p$ & luottamusväli & Cohenin $d$ \\
\hline 3. lk-6. lk & $-30,25$ & 218 & $<0,001$ & {$[-190,71 ;-167,38]$} & 2,34 \\
\hline 6. $1 \mathrm{k}-9.1 \mathrm{k}$ & $-30,28$ & 244 & $<0,001$ & {$[-139,86 ;-122,77]$} & 2,04 \\
\hline 3. $1 \mathrm{k}-9.1 \mathrm{k}$ & $-57,55$ & 218 & $<0,001$ & {$[-322,32 ;-300,97]$} & 4,53 \\
\hline
\end{tabular}

Kuviossa 5 on kuvattu hyvien ja parhaiden osaajien sekä muiden otokseen kuuluvien oppilaiden osaamisen muutokset perusopetuksen aikana. Kuviosta nähdään, että jo lähtötaso on ollut keskimäärin selkeästi korkeampi sekä parhailla että hyvillä osaajilla muuhun tutkimusjoukkoon nähden. Lisäksi osaamisen kasvu on ollut jyrkkää koko perusopetuksen ajan, kun taas muun tutkimusjoukon osaamisen kasvu on selvästi hidastunut kuudennen vuosiluokan jälkeen. 
Kuvio 5. Osaamisen muutokset perusopetuksen aikana.

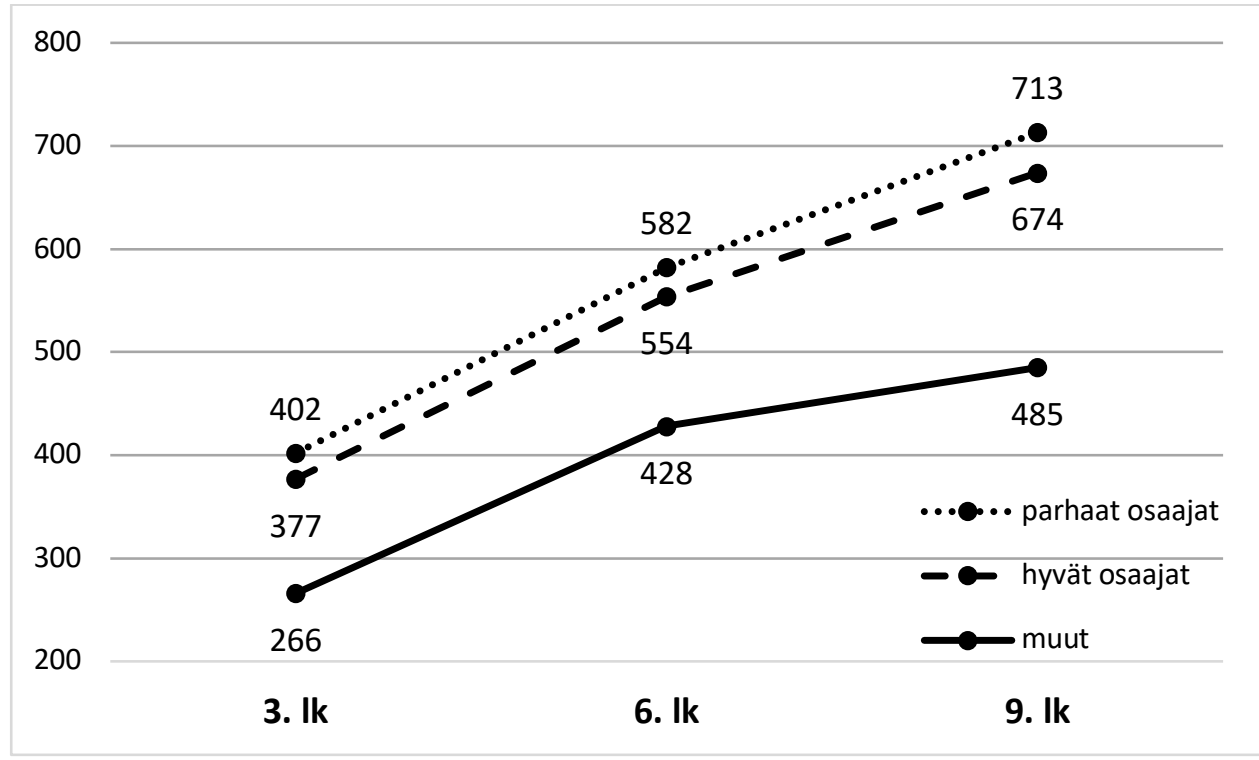

\section{Mikä erottaa parhaat osaajat muista?}

Matematiikan osaamista mittaavien kokeiden lisäksi oppilaat ovat vastanneet asenteita kartoittaviin kysymyksiin. Heiltä ja opettajilta on myös kerätty erilaista taustatietoa oppimiseen ja opetukseen liittyen sekä tietoja demografisista tekijöistä. Seuraavaksi esitellään muuttujia, joiden nähdään olevan yhteydessä siihen, kuuluuko oppilas parhaiden osaajien joukkoon yhdeksännellä vuosiluokalla. Tarkastelun kohteena on ainoastaan tutkimusjoukon ylin desiili.

Ensiksi esitellään demografisia tekijöitä, joihin kuuluvat sukupuoli, alueellinen sijainti ja vanhempien koulutustaso. Toiseksi tarkastellaan aikaisemman osaamisen selitysosuutta yhdeksännen vuosiluokan osaamisen vaihtelusta. Aikaisemmassa osaamisessa otetaan matematiikan lisäksi huomioon äidinkielen osaaminen. Kolmantena käsitellään matematiikkaan liittyvien asenteiden selitysosuutta osaamistasoon ensin kolmannen ja kuudennen vuosiluokan ja näiden jälkeen myös yhdeksännen vuosiluokan osalta. Lopuksi tarkastellaan vielä opetuksellisten tekijöiden yhteyttä osaamistasoon.

\section{Demografiset tekijät}

Sukupuolten välistä eroa yhdeksännen vuosiluokan parhaiden osaajien osaamisessa ei ole havaittavissa kolmannella tai kuudennella vuosiluokalla. Tilastollinen ero osaamisessa on nähtävissä yhdeksännellä vuosiluokalla (taulukko 6). Poikien osuus parhaiden osaajien joukossa on tyttöjä suurempi (ero 20,4 prosenttiyksikköä), mutta myös osaamisen taso on tyttöjä parempaa. Keskiarvojen välinen ero on tilastollisesti erittäin merkitsevä yhdeksännen vuosiluokan kokeessa $\mathrm{t}(251,97)=3,56$; $\mathrm{p}=<0,000$. Tuloksista havaitaan myös, että parhaiden poikien pisteiden hajonta on suurempaa kuin tyttöjen. 
Ainedidaktiikka 4(1) (2020)

Taulukko 6. Parhaiden osaajien sukupuolten väliset erot 9. luokan koepisteissä.

\begin{tabular}{lll}
$\begin{array}{l}\text { Koepisteet 9. luokalla } \\
\text { (PISA-asteikko) }\end{array}$ & $\begin{array}{l}\text { pojat } \\
\mathbf{n}=\mathbf{1 5 4}\end{array}$ & $\begin{array}{l}\text { tytöt } \\
\mathbf{n}=\mathbf{1 0 2}\end{array}$ \\
\hline keskiarvo & 721,4 & 699,1 \\
minimi & 657,1 & 654,2 \\
maksimi & 1029,5 & 866,3 \\
keskihajonta & 63,1 & 37,2
\end{tabular}

Seuraavassa taulukossa 7 nähdään oppilaiden alueellinen sijoittuminen osaamisryhmien mukaan. Alueellisessa jakamisessa on käytetty entistä läänijakoa. Taulukosta 7 havaitaan, että Itä- ja Etelä-Suomen lääneissä on osallistujamääriin nähden enemmän parhaita ja hyviä osaajia kuin muissa lääneissä. Itä-Suomen läänistä osallistuneista oppilaista enemmän kuin joka kolmas $(34,1 \%)$ kuuluu hyvien tai parhaiden osaajien joukkoon. Myös Etelä-Suomen läänissä osallistuneista joka neljäs (24,8 \%) kuuluu parhaisiin tai hyviin osaajiin. Khiin neliö -testin mukaan läänin ja oppilaan osaamisryhmän välillä on tilastollisesti erittäin merkitsevä riippuvuus $\left(\chi^{2}(8)=29,60 ; p=<0,001\right.$; Cramerin $\left.V=0,09\right)$. Myös varianssianalyysin mukaan läänin yhteys osaamisen tasoon on tilastollisesti erittäin merkit$\operatorname{sevä~}(\mathrm{F}(4,2044)=6,01 ; p=<0,001)$.

Taulukko 7. Osaamisryhmät läänijaoittain.

$\begin{array}{lllll}\text { lääni } & \begin{array}{l}\text { parhaat osaajat } \\ \mathbf{n}=\mathbf{2 5 6}\end{array} & \begin{array}{l}\text { hyvät osaajat } \\ \mathbf{n}=\mathbf{2 2 6}\end{array} & \begin{array}{l}\text { muut osaajat } \\ \mathbf{n = 1 5 6 7}\end{array} & \text { yhteensä } \\ \begin{array}{l}\text { Etelä-Suomen } \\ \text { lääni }\end{array} & 91(14,2 \%) & 68(10,6 \%) & 480(75,1 \%) & 639(100 \%) \\ \begin{array}{l}\text { Länsi-Suomen } \\ \text { lääni }\end{array} & 88(10,2 \%) & 86(10,0 \%) & 686(79,8 \%) & 860(100 \%) \\ \begin{array}{l}\text { Itä-Suomen lääni } \\ \text { Oulun lääni }\end{array} & 51(19,3 \%) & 39(14,8 \%) & 174(65,9 \%) & 264(100 \%) \\ \text { Lapin lääni } & 21(11,1 \%) & 22(11,6 \%) & 146(77,2 \%) & 189(100 \%) \\ & 5(5,2 \%) & 11(11,3 \%) & 81(83,5 \%) & 97(100 \%)\end{array}$

Kokeisiin osallistuneiden oppilaiden vanhempien koulutustasoa on selvitetty ylioppilastutkinnon suorittamisen osalta. Taulukossa 8 nähdään eri osaamisryhmiin kuuluvien oppilaiden ylioppilastutkinnon suorittaneiden vanhempien osuus. Havaitaan, että lähes puolella parhaista osaajista ja lähes 40 prosentilla hyvistä osaajista molemmat vanhemmat ovat ylioppilaita. Sen sijaan muilla oppilailla, jotka kuuluvat osaamistasoltaan 1-8 desiiliin, hieman yli 20 prosenttia molemmista vanhemmista on ylioppilas. Khiin neliö -testin mukaan vanhempien koulutustasolla on tilastollisesti erittäin merkitsevä riippuvuus oppilaan osaamisryhmään $\left(\chi^{2}(4)=\right.$ $81,51 ; p=<0,001$; Cramerin $V=0,15)$. 
Taulukko 8. Vanhempien koulutus osaajaryhmissä.

$\begin{array}{llll}\text { vanhempien koulutus } & \begin{array}{l}\text { parhaat osaajat } \\ \mathbf{n = 2 5 6}\end{array} & \begin{array}{l}\text { hyvät osaajat } \\ \mathbf{n = 2 2 6}\end{array} & \begin{array}{l}\text { muut osaajat } \\ \mathbf{n}=\mathbf{1 5 6 7}\end{array} \\ \text { molemmat ylioppilaita } & 47,3 \% & 37,9 \% & 23,8 \% \\ \text { toinen ylioppilas } & 33,3 \% & 35,0 \% & 34,4 \% \\ \text { kumpikaan ei ylioppilas } & 19,4 \% & 27,1 \% & 41,8 \%\end{array}$

\section{Aikaisempi osaaminen}

Seuraavaksi selvitetään, millainen yhteys matematiikan ja äidinkielen aikaisemmalla osaamisella on yhdeksännen vuosiluokan matematiikan osaamistasoon. Aluksi esitellään matematiikan kolmannen ja kuudennen vuosiluokan koeosaamisen selitysosuutta yhdeksännen vuosiluokan osaamisen vaihteluun. Sen jälkeen selvitetään, miten opettajan antama sanallinen arvio ja matematiikan arvosana selittävät matematiikan osaamista yhdeksännellä vuosiluokalla. Äidinkielen osaamisen selitysosuutta selvitetään opettajan antaman sanallisen arvion ja arvosanatiedon perusteella.

Logistisen regressioanalyysin (taulukko 9) mukaan kolmannen ja kuudennen vuosiluokan koeosaamisen selitysosuus, $R^{2}$ on 0,556 . Aikaisempi koeosaaminen selittää siis 55,6 prosenttia osaamisen vaihtelusta yhdeksännellä vuosiluokalla. Riskitasot $\operatorname{Exp(B)}$ ovat kuitenkin melko alhaiset eli koeosaamisen perusteella on vaikea ennustaa mahdollisuutta kuulua parhaiden osaajien joukkoon yhdeksännellä vuosiluokalla.

Taulukko 9. Koeosaaminen kolmannella ja kuudennella vuosiluokalla.

\begin{tabular}{llllll} 
muuttuja & B & keskivirhe & $\operatorname{Exp}(\mathbf{B})$ & p-arvo \\
\hline koeosaaminen 3. Ik & $<0,01$ & $<0,01$ & 1,01 & $<0,001$ \\
\hline koeosaaminen 6. lk & 0,02 & $<0,01$ & 1,03 & $<0,001$ \\
\hline vakio & $-16,72$ & 0,99 & $<0,001$ & $<0,001$ \\
\hline Mallin selitysaste Nagelkerken $\boldsymbol{R}^{\mathbf{2}}=\mathbf{0 , 5 5 6}$ & & \\
\hline
\end{tabular}

Opettaja on antanut sekä kolmannella että kuudennella vuosiluokalla sanallisen arvion siitä, onko oppilaan matematiikan osaamisen taso opetussuunnitelman hyvän osaamisen kuvausta heikompaa, sen tasoista vai parempaa. Lisäksi kuudennelta vuosiluokalta on saatu tieto oppilaiden matematiikan arvosanasta.

Matematiikan osaaminen sanallisten arvioiden ja arvosanatiedon mukaan selittää 32,6 prosenttia osaamisen vaihtelusta yhdeksännellä vuosiluokalla (taulukko 10). Mallin mukaan oppilaalla, jonka matematiikan osaaminen on ollut 3. vuosiluokalla kuvauksen tasoista tai sitä parempaa, on 7-kertainen mahdollisuus kuulua parhaiden osaajien joukkoon 9. vuosiluokalla. Kuudennen vuosiluokan sanallisen arvion perusteella vastaava mahdollisuus on 8-kertainen. Mallin mukaan oppilaalla on lähes 13-kertainen mahdollisuus kuulua parhaiden osaajien joukkoon, jos oppilaan matematiikan arvosana 6. vuosiluokalla on ollut 8,9 tai 10. 
Taulukko 10. Matematiikan aikaisempi osaaminen opettajan sanallisten arvioiden ja arvosanatiedon perusteella.

\begin{tabular}{|l|l|l|l|l} 
muuttuja & B & keskivirhe & $\operatorname{Exp}(\mathbf{B})$ & p-arvo \\
\hline $\begin{array}{l}\text { matematiikan osaaminen kuvauk- } \\
\text { sen tasoista tai parempaa (3. lk) }\end{array}$ & 1,95 & 0,73 & 7,05 & 0,008 \\
\hline $\begin{array}{l}\text { matematiikan osaaminen kuvauk- } \\
\text { sen tasoista tai parempaa (6. lk) }\end{array}$ & 2,13 & 0,74 & 8,41 & 0,004 \\
\hline $\begin{array}{l}\text { matematiikan arvosana 8, 9 tai 10 } \\
\text { (6. Ik) }\end{array}$ & 2,56 & 0,31 & 12,88 & $<0,001$ \\
\hline vakio & $-7,47$ & 0,99 & 0,001 & $<0,001$ \\
\hline Mallin selitysaste Nagelkerken $\boldsymbol{R}^{\mathbf{2}}=\mathbf{0 , 3 2 6}$ & & & \\
\hline
\end{tabular}

Kolmannen ja kuudennen vuosiluokan äidinkielen osaaminen selittää 12,6 prosenttia osaamisen vaihtelusta yhdeksännellä vuosiluokalla (taulukko 11). Mallin mukaan oppilaalla on nelinkertainen mahdollisuus kuulua parhaiden osaajien joukkoon 9. vuosiluokalla, jos oppilaan äidinkielen osaaminen 3. vuosiluokalla on ollut kuvauksen tasoista tai sitä parempaa. Kuudennen vuosiluokan arvosanatiedon perusteella oppilaalla on noin kolminkertainen mahdollisuus kuulua parhaiden osaajien joukkoon, jos äidinkielen arvosana on ollut 8, 9 tai 10 .

Taulukko 11. Äidinkielen osaaminen kolmannella ja kuudennella vuosiluokalla.

\begin{tabular}{l|l|l|l|l} 
muuttuja & B & keskivirhe & $\operatorname{Exp(B)}$ & p-arvo \\
\hline $\begin{array}{l}\text { äidinkielen osaaminen } \\
\text { kuvauksen tasoista tai } \\
\text { parempaa (3. lk) }\end{array}$ & 1,47 & 0,32 & 4,34 & $<0,001$ \\
\hline $\begin{array}{l}\text { äidinkielen arvosana 8, } \\
\text { 9 tai 10 (6. lk) }\end{array}$ & 1,01 & 0,17 & 2,76 & $<0,001$ \\
\hline vakio & $-3,64$ & 0,30 & 0,03 & $<0,001$ \\
\hline
\end{tabular}

Mallin selitysaste Nagelkerken $R^{2}=\mathbf{0 , 1 2 6}$

Asenteet kolmannella ja kuudennella vuosiluokalla

Oppilaan suhtautumista matematiikkaan on selvitetty kolmannella vuosiluokalla matematiikan pitämiseen ja minäkuvaan liittyvien väitteiden avulla. Kuudennella vuosiluokalla näiden lisäksi on selvitetty, kuinka hyödylliseksi oppilas kokee matematiikan opiskelun. Asenteisiin liittyvät muuttujat ovat analyyseissa mukana summamuuttujina, jotka on esitetty taulukoissa lyhenteillä summa PITÄÄ (matematiikasta pitäminen), summa OSAA (minäkuva eli käsitys omasta matematiikan osaamisesta) ja summa HYÖTY (käsitys matematiikan hyödyllisyydestä).

Asenteiden selitysosuus R2 on 0,247, eli kolmannen ja kuudennen vuosiluokan asenteet selittävät 24,7 prosenttia yhdeksännen vuosiluokan osaamisen vaihtelusta. Taulukosta 12 nähdään, että käsitys omasta osaamisesta on asenteista ainut muuttuja, joka vaikuttaa malliin tilastollisesti 
merkitsevästi sekä kolmannen että kuudennen vuosiluokan osalta. Erityisesti kuudennen vuosiluokan muuttujan vaikutus on suuri ja mahdollisuus kuulua parhaiden osaajien joukkoon on lähes viisinkertainen.

Taulukko 12. Matematiikkaan liittyvät asenteet kolmannella ja kuudennella vuosiluokalla.

\begin{tabular}{l|l|l|l|l} 
muuttuja & B & keskivirhe & $\operatorname{Exp(B)}$ & p-arvo \\
\hline summa PITÄÄ 3. lk & $-0,11$ & 0,11 & 0,90 & 0,30 \\
\hline summa OSAA 3. lk & 0,47 & 0,16 & 1,60 & 0,004 \\
\hline summa PITÄ̈̈ 6. lk & $-0,09$ & 0,09 & 0,92 & 0,35 \\
\hline summa OSAA 6. lk & 1,58 & 0,16 & 4,85 & $<0,001$ \\
\hline summa HYÖTY 6. lk & 0,29 & 0,15 & 1,34 & 0,05 \\
\hline vakio & $-5,11$ & 0,53 & 0,01 & $<0,001$ \\
\hline Mallin selitysaste Nagelkerken $\boldsymbol{R}^{\mathbf{2}} \mathbf{0 , 2 4 7}$ & & \\
\hline
\end{tabular}

Asennoituminen matematiikkaan ja sen opiskeluun yhdeksännellä vuosiluokalla

Matematiikkaan liittyviä asenteita on selvitetty yhdeksännellä vuosiluokalla pitämisen, minäkuvan ja oppiaineen hyödylliseksi kokemisen osalta. Yhdeksännen vuosiluokan asenteet selittävät 20,8 prosenttia osaamisen vaihtelusta. Taulukossa 13 on kuvattu regressioanalyysin tulokset. Tuloksista havaitaan, että käsitys omasta osaamisesta selittää parhaiten osaamisryhmään kuulumista. Minäkuvan riskitaso, $\operatorname{Exp}(B)$ on 2,93 eli mahdollisuus kuulua parhaiden osaajien joukkoon on kolminkertainen.

Taulukko 13. Matematiikkaan liittyvät asenteet yhdeksännellä vuosiluokalla.

\begin{tabular}{l|l|l|l|l} 
muuttuja & B & keskivirhe & $\operatorname{Exp(B)}$ & p-arvo \\
\hline summa PITÄÄ 9. lk & 0,27 & 0,11 & 1,31 & 0,010 \\
\hline summa OSAA 9. lk & 1,08 & 0,12 & 2,93 & $<0,001$ \\
\hline summa HYÖTY 9. lk & $-0,03$ & 0,11 & 0,97 & 0,811 \\
\hline vakio & $-5,00$ & 0,33 & 0,00 & $<0,001$ \\
\hline Mula
\end{tabular}

Mallin selitysaste Nagelkerken $\boldsymbol{R}^{2}=\mathbf{0 , 2 0 8}$

Oppilailta on selvitetty, kuinka paljon he käyttävät aikaa matematiikan kokeeseen valmistautumiseen ja miten hyvin he huolehtivat oman arvionsa mukaan annetuista kotitehtävistä. Näiden muuttujien voidaan ajatella liittyvän ahkeruuteen. Matematiikan kokeeseen valmistautumiseen ja kotitehtävien tekemiseen liittyvien muuttujien selitysosuus yhdeksännen vuosiluokan osaamisryhmään oli 0,112 . Taulukossa 14 näkyy, että muuttujat vaikuttavat malliin tilastollisesti erittäin merkitsevästi. Kokeisiin valmistautuminen saa mallissa kuitenkin negatiivisen arvon, mikä tässä tapauksessa viittaa siihen, että parhaat osaajat käyttävät muihin nähden vähemmän aikaa kokeisiin valmistautumiseen. 
Taulukko 14. Asennoituminen opiskeluun yhdeksännellä vuosiluokalla.

\begin{tabular}{l|l|l|l|l} 
muuttuja & B & keskivirhe & Exp(B) & p-arvo \\
\hline $\begin{array}{l}\text { Kuinka paljon käytät aikaa } \\
\text { valmistautuessasi matematii- } \\
\text { kan kokeeseen? }\end{array}$ & $-0,65$ & 0,08 & 0,52 & $<0,001$ \\
\hline $\begin{array}{l}\text { Annetut kotitehtävät olen } \\
\text { tehnyt sovitulla tavalla. }\end{array}$ & 0,62 & 0,08 & 0,06 & $<0,001$ \\
\hline vakio & $-2,82$ & 0,36 & 0,06 & $<0,001$ \\
\hline
\end{tabular}

Mallin selitysaste Nagelkerken $\boldsymbol{R}^{2}=\mathbf{0 , 1 1 2}$

\section{Opetukselliset tekijät}

Yhdeksännellä vuosiluokalla oppilailta on kerätty tietoa opetuksen järjestämisestä ja muista opetuksellisista tekijöistä. Logistisen regressioanalyysin mukaan opetuksellisten tekijöiden selitysosuus $R^{2}$ on 0,108 eli malli selittää noin 11 prosenttia osaamisen vaihtelusta yhdeksännellä vuosiluokalla. Regressioanalyysissa otettiin mukaan yhteensä 16 muuttujaa, joista taulukkoon 15 on koottu malliin tilastollisesti merkitsevästi vaikuttavat muuttujat.

Taulukko 15. Opetukselliset tekijät regressioanalyysin ennustemallissa.

\begin{tabular}{|l|l|l|l|l|}
\hline muuttuja & B & \multicolumn{1}{|c|}{ keskivirhe } & \multicolumn{1}{|c|}{$\mathbf{E x p ( B )}$} & p-arvo \\
\hline opetusryhmän koko & 0,30 & 0,09 & 1,34 & 0,002 \\
\hline joustava ryhmittely & $-0,84$ & 0,21 & 0,43 & $<0,001$ \\
\hline $\begin{array}{l}\text { yhteistä opetusta opettajan } \\
\text { johdolla }\end{array}$ & 0,32 & 0,10 & 1,38 & 0,001 \\
\hline $\begin{array}{l}\text { kukin ratkaisee itselleen } \\
\text { sopivan vaikeita tehtäviä }\end{array}$ & 0,21 & 0,08 & 1,24 & 0,006 \\
\hline $\begin{array}{l}\text { pohditaan tehtävien } \\
\text { vastausten järkevyyttä }\end{array}$ & 0,22 & 0,08 & 1,25 & 0,008 \\
\hline $\begin{array}{l}\text { oppilaat asettavat itselleen } \\
\text { tavoitteita ja arvioivat } \\
\text { edistymistään }\end{array}$ & $-0,47$ & 0,09 & 0,63 & $<0,001$ \\
\hline \begin{tabular}{l} 
vakio \\
\hline
\end{tabular} & $-2,52$ & 0,79 & 0,08 & 0,001 \\
\hline
\end{tabular}

Mallin selitysaste Nagelkerken $\boldsymbol{R}^{2}=0,108$

Tuloksista havaitaan, että kaksi muuttujaa (joustava ryhmittely ja oppilaat asettavat itselleen tavoitteita ja arvioivat edistymistään) saavat negatiiviset arvot. Joustava ryhmittely tai omien tavoitteiden ja edistymisen arviointi eivät edesauta kuulumista parhaiden osaajien ryhmään. Opetuksellisten tekijöiden osuudet osaajaryhmää ennustettaessa ovat pienet.

\section{Osaamistason kasvu 3. vuosiluokan keskitasoa heikommasta parhai- den osaajien tasolle 9. vuosiluokalla}

Tutkimusaineistossa havaittiin oppilaita, jotka kuuluvat yhdeksännellä vuosiluokalla parhaiden osaajien joukkoon, mutta osaamisen taso kolmannella tai kuudennella vuosiluokalla on ollut keskitasoa heikompaa. 
Tarkoituksena on selvittää, mitkä tekijät selittävät osaamisen kasvua keskitasoa heikommasta osaamistasosta parhaiden osaajien tasolle.

Tutkimusaineistosta on valittu tutkimusryhmäksi oppilaat, jotka ovat kuuluneet 3. vuosiluokan kokeen perusteella osaamistasoltaan desiileihin 2-6, mutta osaaminen on kasvanut desiilin 9 tai 10 tasolle yhdeksännen vuosiluokan päättyessä. Tällaisia oppilaita on aineistossa yhteensä 77 , joista poikia on $40(51,9 \%)$ ja tyttöjä $37(48,1 \%)$. Taulukossa 16 on kuvattu tämän tutkimusjoukon perustietoja. Taulukosta näkyy, että kieliryhmän osalta viidesosa tutkimusjoukkoon kuuluvista oppilaista on ruotsinkielisiä. Näistä oppilaista myös kotikielenään ruotsia puhuu suhteellisesti enemmän kuin koko otoksessa. Suomi toisena kielenä -opetusta saaneita on tutkimusjoukossa 22,9 prosenttia. Koko otoksessa suomi toisena kielenä -opetusta saaneita oppilaita on 15,5 prosenttia. Läänijaon mukaan tarkasteltuna oppilaita, joiden osaaminen on kasvanut keskitasoa heikommasta parhaiden osaajien tasolle, löytyy eniten Itä-Suomen läänistä suhteessa samasta läänistä osallistuneisiin muihin oppilaisiin. Oulun ja Lapin läänien osalta tuloksia on vaikea tulkita, koska otoskoko on jo lähtökohtaisesti pieni.

Taulukko 16. Keskitasoa heikompaan lähtötasoon kuuluvan tutkimusjoukon perustietoja.

\begin{tabular}{|c|c|c|c|c|}
\hline & & $\begin{array}{l}\text { keskitasoa hei- } \\
\text { kommasta par- } \\
\text { haaksi osaa- } \\
\text { jaksi } \\
(\mathbf{n}=77)\end{array}$ & $\begin{array}{l}\text { parhaat osaajat } \\
(\mathbf{n}=\mathbf{2 5 6})\end{array}$ & $\begin{array}{l}\text { koko otos } \\
(\mathrm{n}=\mathbf{2 0 5 1})\end{array}$ \\
\hline \multirow[t]{2}{*}{ sukupuoli } & tyttö & $48,1 \%$ & $39,8 \%$ & $49,2 \%$ \\
\hline & poika & $51,9 \%$ & $60,2 \%$ & $50,8 \%$ \\
\hline \multirow[t]{2}{*}{ kieliryhmä } & suomi & $79,2 \%$ & $90,6 \%$ & $87,7 \%$ \\
\hline & ruotsi & $20,8 \%$ & $9,4 \%$ & $12,3 \%$ \\
\hline \multirow[t]{4}{*}{ kotikieli } & suomi & $80,5 \%$ & $89,8 \%$ & $86,7 \%$ \\
\hline & ruotsi & $11,7 \%$ & $4,7 \%$ & $7,7 \%$ \\
\hline & suomi ja ruotsi & $6,5 \%$ & $3,5 \%$ & $3,5 \%$ \\
\hline & jokin muu & $1,3 \%$ & $2,0 \%$ & $2,2 \%$ \\
\hline \multirow{2}{*}{$\begin{array}{l}\text { suomi toi- } \\
\text { sena kielenä } \\
\text {-opetus }\end{array}$} & kyllä & $22,9 \%$ & $10,2 \%$ & $15,5 \%$ \\
\hline & ei & $77,1 \%$ & $89,8 \%$ & $84,5 \%$ \\
\hline \multirow{3}{*}{$\begin{array}{l}\text { kunta- } \\
\text { ryhmä }\end{array}$} & kaupunki & $58,4 \%$ & $63,7 \%$ & $54,7 \%$ \\
\hline & taajama & $16,9 \%$ & $16,0 \%$ & $21,6 \%$ \\
\hline & maaseutu & $24,7 \%$ & $20,3 \%$ & $23,7 \%$ \\
\hline \multirow[t]{5}{*}{ lääni } & Etelä-Suomi & $31,2 \%$ & $35,5 \%$ & $31,2 \%$ \\
\hline & Länsi-Suomi & $37,7 \%$ & $34,4 \%$ & $42,0 \%$ \\
\hline & Itä-Suomi & $20,8 \%$ & $19,9 \%$ & $12,9 \%$ \\
\hline & Oulu & $0,8 \%$ & $8,2 \%$ & $9,2 \%$ \\
\hline & Lappi & $0,3 \%$ & $2,0 \%$ & $4,7 \%$ \\
\hline
\end{tabular}

Parhaiden osaajien, joiden osaamisen taso on ollut keskitasoa heikompaa kolmannella vuosiluokalla, osaamisen kasvu on ollut erityisen jyrkkä kolmannelta vuosiluokalta kuudennelle. Tämä havaitaan kuviossa 6. Osaaminen on lisääntynyt 177 pisteellä (+92,9 \%) kolmannelta vuosiluokalta 
kuudennelle, 120 pisteellä (+25,7 \%) kuudennelta vuosiluokalta yhdeksännelle ja koko perusopetuksen aikana jopa 297 pisteellä (+142,5 \%). Nämä oppilaat saavuttavat melkein muiden parhaiden osaajien joukon jo kuudennella vuosiluokalla.

Kuvio 6. Osaamisen muutokset perusopetuksen aikana (mukana parhaat osaajat, joiden osaaminen keskitasoa heikompaa 3. vuosiluokalla).

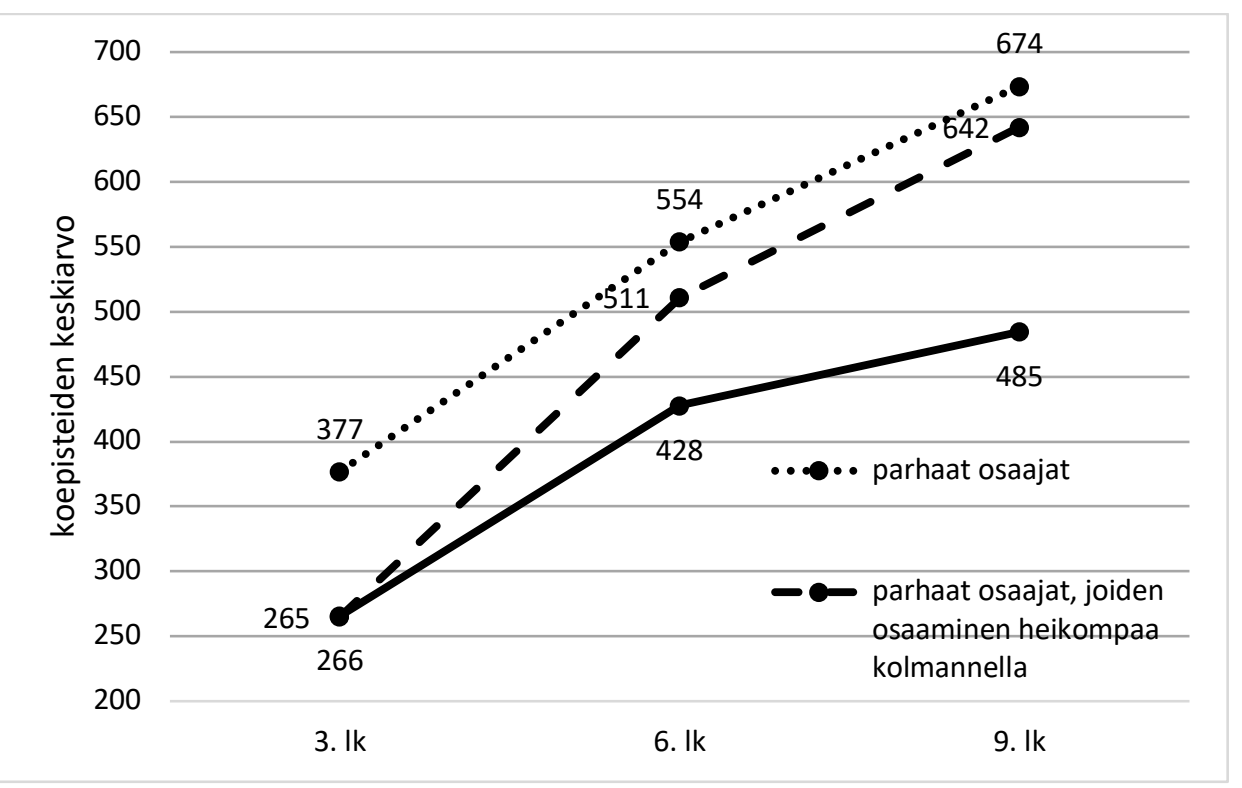

Oppilailta on kerätty tietoja muun muassa kieliryhmästä, alueellisesta sijainnista, kiusaamisesta, tuki- ja eritysopetuksesta ja asenteista ja vanhempien koulutustasosta. Näistä ei kuitenkaan löydy selkeitä selittäviä tekijöitä osaamisen eriytymiselle.

Osalla oppilasta, joiden osaaminen on kasvanut keskitasoa heikommasta parhaiden osaajien tasolle, heikkoa lähtötasoa saattaa selittää äidinkielen osaaminen kolmannella vuosiluokalla. Oppilaista lähes viidesosalla (18,9\%, 14 oppilasta) äidinkielen osaaminen on ollut opettajan antaman arvion mukaan äidinkielen hyvän osaamisen kuvausta heikompaa. Taulukossa 17 nähdään, että vastaavasti parhaista osaajista vain kuudella prosentilla äidinkielen osaaminen on ollut kolmannella vuosiluokalla kuvausta heikompaa ja kolmanneksella huomattavasti parempaa kuin kuvauksessa.

Taulukko 17. Äidinkielen osaaminen kolmannella vuosiluokalla.

$\begin{array}{llll}\begin{array}{l}\text { äidinkielen osaaminen } \\ \text { 3. luokalla }\end{array} & \begin{array}{l}\text { heikoista parhaiksi } \\ \mathbf{n}=\mathbf{7 7}\end{array} & \begin{array}{l}\text { parhaat osaajat } \\ \mathbf{n}=\mathbf{2 5 6}\end{array} & \begin{array}{l}\text { koko otos } \\ \mathbf{n}=\mathbf{2 0 5 1}\end{array} \\ \begin{array}{l}\text { heikompaa kuin } \\ \text { kuvauksessa } \\ \text { kuvauksen tasoista }\end{array} & 18,9 \% & 5,8 \% & 27,6 \% \\ & 68,9 \% & 60,6 \% & 57,9 \% \\ \begin{array}{l}\text { huomattavasti parem- } \\ \text { paa kuin kuvauksessa }\end{array} & 12,2 \% & 33,7 \% & 14,5 \%\end{array}$




\section{Pohdinta}

2000-luvun PISA ja TIMSS-tutkimukset osoittavat, että suomalaislasten ja -nuorten osaaminen on edelleen kansainvälisesti vertailtuna huipputasoa, vaikka samalla heikkojen osaajien määrä on kasvanut ja huippuosaajien määrä on vähentynyt. Poikien oppimistulokset ovat yleisesti heikentyneet ja tytöt ovat saavuttaneet osaamistasossa pojat. Myös asenteissa on tapahtunut laskua (mm. Kupari \& Hiltunen, 2018). Tässä tutkimuksessa selvitettiin, millaisia perusopetuksen parhaat osaajat ovat, milloin heidän osaamistasonsa määräytyy ja mitkä tekijät selittävät menestyksekästä osaamista.

Parhaat osaajat on määritetty tutkimuksessa yhdeksännen vuosiluokan kokeessa menestymisen perusteella. Voidaan pohtia, onko yksittäisen kokeen perusteella tehty arvio osaamisen tasosta luotettava. Muun muassa heikkojen osaajien määrittämisessä on aikaisemmissa tutkimuksissa (mm. Räsänen, Närhi \& Aunio, 2010) käytetty 1,5 keskihajontayksikön rajausta. Desiilien mukaan rajaamisessa tämä rajaus tulee huomioitua. Ylimpään desiiliin kuuluvien oppilaiden keskimääräinen kokeesta saatu pistemäärä on noin 1,7 keskihajontayksikön päässä koko otoksen keskiarvosta. Osaamisen tasoa voidaan tarkastella myös matematiikasta saatujen arvosanojen perusteella. Yhdeksännen vuosiluokan arvosanatietojen perusteella puolet parhaista osaajista on saanut matematiikasta arvosanan 10 (erinomainen) ja lopuista suurin osa $(36,3 \%)$ arvosanan 9 (kiitettävä). Kokeessa mitattu osaamisen taso näyttää olevan matematiikan arvosanatietojen kanssa melko yhteneväinen.

Oppilaiden osaamistaso määräytyy koeosaamisen perusteella, joten ei voida ottaa kantaa matemaattiseen lahjakkuuteen, vaan puhutaan matemaattisesta kyvykkyydestä. Ruokamon (2000) jaottelun mukaan kyseessä on juurikin koulukyvykkyys, joka ilmenee koulussa opiskeltavien sisältöjen hallitsemisena ja kykynä suorittaa matemaattisia testejä. Matemaattiseen lahjakkuuteen liittyvä osa-alue keskitason ylittävästä kyvykkyydestä kuitenkin täyttyy. Lisäksi Renzullin ja Reisin (1985) malli tunnistaa lahjakkuuden osa-alueena opiskelumotivaation, joka ilmenee myös tässä tutkimuksessa asenteita koskevissa tuloksissa.

Tutkimus osoittaa, että matematiikan parhaat osaajat on erotettavissa muusta joukosta jo kolmannella vuosiluokalla ja erot näkyvät selvästi kuudennella vuosiluokalla. Parhaista osaajista lähes 65 prosenttia sijoittuu jo silloin ylimpään osaamistasoa kuvaavaan desiiliin. Myös regressioanalyysin tulokset osoittavat, että oppilaan aikaisempi osaaminen on merkittävä selittäjä sille, kuuluuko oppilas yhdeksännellä vuosiluokalla parhaiden osaajien joukkoon vai ei, mutta osaamistason ennustaminen aikaisemman osaamisen perusteella on vaikeaa. Lisäksi tulokset osoittavat, että parhaiden osaajien osaaminen kasvaa tasaisemmin kuin muun tutkimusjoukon, jonka osaamisen kasvu selvästi hidastuu kuudennen vuosiluokan jälkeen. Myös muun muassa suomalaisen koulunaloitusta käsittelevän tutkimuksen (Aunola, Leskinen, Lerkkanen \& Nurmi, 2004) tulokset osoittavat, että koulunkäynnin edetessä lasten erot matemaattisissa taidoissa kasvavat. Tutkimuksen mukaan lapset, joilla on hyvät matemaattiset valmiudet esiopetusvuoden alussa, kehittyvät taidoissaan 
selvästi nopeammin kuin heikomman lähtötason omaavat lapset ja esiopetusikäisen lapsen matemaattiset taidot selittävät matemaattisia taitoja vielä yläkouluiässäkin.

Useat tutkimukset (mm. Tang, Wang, Guo \& Salmela-Aro, 2019; Duckworth \& Seligman, 2005; Keltikangas-Järvinen, 2007) ovat tuottaneet tietoa motivaation ja ahkeruuden yhteydestä koulumenestykseen. Tässä tutkimuksessa ahkeruuden yhteyttä osaamistasoon tutkittiin kokeisiin valmistautumiseen käytettävän ajan ja kotitehtävien tekemisen näkökulmasta. Näihin liittyvien muuttujien selitysosuus osaamistason määrittäjänä oli pieni ja toisaalta parhaat osaajat käyttävät jopa vähemmän kuin muut aikaa kokeisiin valmistautumiseen. Tästä voidaan päätellä, että parhaat osaajat osaavat asiat jo ilman lisäharjoittelua. Ahkeruuteen liittyvää näkökulmaa olisi mielenkiintoista tutkia enemmän, mutta tämän tutkimusaineiston osalta se ei ole laajemmin mahdollista.

Asenteita koskevien tutkimustulosten osalta käsitys omasta osaamisesta oli tilastollisesti merkitsevä muuttuja osaamistasoa selittäessä. Oppilaan käsitys omasta osaamisesta oli vahva selittävä muuttuja sen suhteen, kuuluuko oppilas yhdeksännellä vuosiluokalla parhaiden osaajien joukkoon. Matematiikan osaamisen ja minäkuvan välinen vuorovaikutus on havaittu useissa eri tutkimuksissa. Esimerkiksi PISA12-tulosten (Kupari ym., 2013) mukaan matematiikan osaamisen ja matemaattisen minäkuvan välillä on vahva yhteys. Vahvan matemaattisen minäkuvan omaavilla oppilailla on selvästi parempi matematiikan osaaminen kuin heikon minäkuvan omaavilla oppilailla. Matemaattisen minäkuvan äärineljänneksiin sijoittuvien oppilaiden erot matematiikan osaamisessa vastaavat jopa kolmen kouluvuoden eroa (Kupari ym., 2013, s. 61). Hannula, Bofah, Tuohilampi ja Metsämuuronen (2014) ovat selvittäneet osaamisen ja asenteiden välistä suhdetta. Tutkimusaineistona on käytetty tämän tutkimuksen kanssa vastaavaa Karvin pitkittäisaineistoa kolmannelta vuosiluokalta yhdeksännelle. Tulosten mukaan pääosin osaaminen vahvistaa minäkuvaa alakoulun aikana kolmannelta vuosiluokalta kuudennelle ja suhde osaamisen ja minäkuvan välillä on vastavuoroinen kuudennelta vuosiluokalta yhdeksännelle.

Vaikka suomalainen matematiikan opetus on tasa-arvoista erilaisista sosioekonomisista taustoista tuleville oppilaille, kotitaustan nähdään kuitenkin olevan yhteydessä oppimistuloksiin. Muun muassa OECD:n (2018) Education at a Glance -julkaisu osoittaa, että vanhempien koulutustaso vaikuttaa voimakkaasti lapsen koulutuspolkuun ja kotitaustan yhteys oppimistuloksiin on voimistunut Suomessa 2010-luvulla. Myös tässä tutkimuksessa vanhempien koulutustasolla havaittiin olevan tilastollisesti erittäin merkitsevä yhteys siihen, mihin osaamisryhmään oppilas kuuluu. Tasa-arvon edistäminen haastaa enemmän koulutuksen järjestäjiä.

Yleisesti poikien oppimistulokset ovat heikentyneet ja tytöt ovat saavuttaneet osaamistasossa pojat (mm. Kupari ym., 2013). Tämä tutkimus kuitenkin osoittaa, että poikien osuus parhaiden osaajien joukossa on tyttöjä suurempi ja myös huippuosaajia on poikien joukossa enemmän. Poikien koulumenestys on yleisesti heikentynyt tyttöihin nähden, mutta poikien yliedustus parhaiden osaajien joukossa näkyy muissakin 
tutkimuksissa, kuten laajassa metropolialueen nuorten osaamista ja hyvinvointia seuraavassa MetLoFIN-tutkimuksessa yläkoulun alusta läpi toisen asteen koulutuksen (Hotulainen ym., 2016).

Tuloksista havaitaan, että kaksi muuttujaa (joustava ryhmittely ja oppilaat asettavat itselleen tavoitteita ja arvioivat edistymistään) saavat negatiiviset arvot. Joustava ryhmittely tai omien tavoitteiden ja edistymisen arviointi eivät edesauta kuulumista parhaiden osaajien ryhmään. Opetuksellisten tekijöiden osuudet osaajaryhmää ennustettaessa ovat pienet.

Tutkimus osoittaa, että heikosta lähtötasosta huolimatta oppilaan on mahdollista perusopetuksen aikana kehittyä matematiikan osaamisessaan jopa erinomaiselle tasolle. Osaamisen kasvu on ollut erityisen jyrkkää, ja lähtötasoltaan keskitasoa heikommat osaajat yltävät jo kuudennella vuosiluokalla samalle tasolle muiden parhaiden osaajien kanssa. Selkeitä selittäviä tekijöitä tälle ei kuitenkaan tutkimuksessa löytynyt, mikä saattaa selittyä suhteellisen pienellä kohdejoukolla. Toki matematiikan osaamisen kehittymiseen vaikuttaa moni asia yhdessä eikä kaikkia tekijöitä pystytä tämän tutkimuksen avulla löytämään. Tässä tutkimuksessa heikkoa menestystä kolmannen luokan kokeessa voi selittää esimerkiksi heikko lukutaito alkuopetuksen päättyessä, satunnainen epäonnistuminen kokeessa tai opettajan vaihtuminen. Ainakin suomi toisena kielenä -opetusta saaneiden oppilaiden (22,9\%) osaamisen tasoa selittänee suomen kielen heikompi osaaminen. Tuloksista ilmeni myös, että keskitasoa heikommasta lähtötasosta parhaiden osaajien joukkoon kuuluvissa oppilaissa oli koko otokseen verrattuna suhteellisesti enemmän ruotsinkielisiä oppilaita. Sama on ollut havaittavissa yleiselläkin tasolla, kun ruotsinkieliset opiskelijat ovat saavuttaneet suomenkielisten tason 9. luokan loppuun mennessä selvästi heikommista lähtökohdista (Metsämuuronen, 2017). Ruotsinkieliset ovat pärjänneet kansainvälisissä vertailututkimuksissa yleisesti suomenkielisiä heikommin, mutta esimerkiksi Pisa12-tutkimuksessa ruotsin- ja suomenkielisten oppilaiden osaamisen ero on tasoittunut suomenkielisten osaamistason heikentyessä (Kupari ym., 2013).

Tutkimustulokset osoittavat joitakin alueellisia eroja parhaiden osaajien joukossa. Itä-Suomen läänistä osallistuneista oppilaista enemmän kuin joka kolmas kuului hyvien tai parhaiden osaajien joukkoon. EteläSuomen läänissäkin joka neljäs kuului parhaisiin tai hyviin osaajiin. Lisäksi oppilaita, joiden osaaminen on kasvanut keskitasoa heikommasta parhaiden osaajien tasolle, on Itä-Suomen läänissä suhteellisesti eniten. Jatkotutkimuksella tulisi selvittää, mistä erot johtuvat. Alueelliset erot oppimistuloksissa ovat yleisesti pieniä, mutta vuoden 2015 PISA-tutkimuksessa (Vettenranta ym., 2016b) havaittiin tilastollisesti erittäin merkitseviä alueiden välisiä eroja pääkaupunkiseudun oppilaiden keskimääräisten tulosten ollessa muuta maata parempia niin luonnontieteissä, matematiikassa kuin lukutaidossakin. Nissinen ja Vuorinen (2018) ovat selittäneet pääkaupunkiseudun parempia oppimistuloksia perheiden sosioekonomisen tason ja kulttuuripääoman lisäksi myös oppilaisen uraodotuksilla. Nissinen ja Vuorinen näkevät, että opinto-ohjauksella ja urasuunnittelutaidoilla on yhteys motivaatioon ja oppimistuloksiin ja näihin tulisi kiinnittää enemmän huomiota.

Tutkimus toi esille kasvavia haasteita tasa-arvoisen koulutuksen järjestämisen näkökulmasta, kun sukupuolen, vanhempien koulutuksen ja 


\section{Ainedidaktiikka 4(1) (2020)}

alueellisen sijainnin osalta oli havaittavissa eriytymistä. Parhaiten menestyneiden oppilaiden joukossa poikien osuus oli tyttöjä suurempi, vanhempien toisen asteen koulutuksella oli tilastollisesti merkitsevä yhteys oppilaan osaamistasoon ja Itä- ja Etelä-Suomen lääneissä oli osallistujamääriin nähden enemmän parhaita osaajia. Perusopetuksessa tulisi kiinnittää enemmän huomiota matemaattisen potentiaalin tunnistamiseen tyttöjen ja niiden oppilaiden osalta, joiden vanhemmilla on vähemmän koulutusta sekä tarjota näille oppilaille sopivantasoisia haasteita. Myös alueellinen tasa-arvo saattaa jäädä toteutumatta parhaiden osaajien kohdalla.

Tutkimusta on tarkoitus jatkaa selvittämällä, miten parhaiden osaajien osaaminen kehittyy toisen asteen aikana ja millaisia valintoja he tekevät opintojen suhteen. On tärkeää selvittää, millaiset tekijät selittävät toista astetta koskevia valintoja sekä miten osaaminen ja asenteet muuttuvat toisella asteella.

\section{Lähteet}

Aunola, K., Leskinen, E., Lerkkanen, M-K. \& Nurmi, J-E. (2004). Developmental dynamics of math performance from preschool to Grade 2. Journal of Educational Psychology, 96(4), 699-713. https://doi.org/10.1037/0022-0663.96.4.699

Bandura, A. (1977). Social learning theory. Englewood Cliffs: Prentice-Hall.

Blau, F. D., Ferber M. A. \& Winkler A. E. (2010). The Economics of Women, Men, and Work, 6th Edition. Englewood Cliffs: Prentice-Hall.

Bloom, B. S. (1976). Human characteristics and school learning. New York, NY: Kingsport Press.

Bryan, R. R., Glynn, S. M. \& Kittleson, J. M. (2011). Motivation, achievement, and advanced placement intent of high school students learning science. Science Education, 95(6), 1049-1065. https://doi.org/10.1002/sce.20462

Cohen, J. (1988). Statistical power analysis for the behavioral sciences. Hillsdale, NJ: Erlbaum.

Crawford, C. \& Cribb, J. (2013). Reading and maths skills at age 10 and earnings in later life: a brief analysis using the British Cohort Study (Vol. REP03). London: Institute for Fiscal Studies.

Davis-Kean, P. E. (2005). The influence of parent education and family income on child achievement: the indirect role of parental expectations and the home environment. Journal of Family Psychology, 19(2), 294-304. https://doi.org/10.1037/0893-3200.19.2.294

Duckworth, A. L. \& Seligman, M. E. P. (2005). Self-discipline outdoes IQ in predicting academic performance of adolescents. Psychological science, 16(12), 939-944. https://doi.org/10.1111/j.1467-9280.2005.01641.x

Else-Quest, N. M, Hyde, J. S. \& Linn, M. C. (2010). Cross-national patterns of gender differences in mathematics: meta-analysis. Psychological Bulletin, 136(1), 103 127. https://doi.org/10.1037/a0018053

Fennema, E. \& Sherman, J. (1976). Fennema-Sherman Mathematics Attitudes Scales: Instruments designed to measure attitudes toward the learning of mathematics. Journal for Research in Mathematics Education, 7(5), 324-326. https://doi.org/10.2307/748467

Hannula, M. S., Bofah, E., Tuohilampi, L. \& Metsämuuronen, J. (2014). A longitudinal analysis of the relationship between mathematics-related affect and achievement in Finland. Teoksessa S. Oesterle, P. Liljedahl, C. Nicol \& D. Allan (toim.), Proceedings of the Joint Meeting of PME 28 and PME-NA 36, Volume 3 (ss. 249256). Vancouver, Canada: PME.

Hannula, M. S. \& Holm, M. E. (2018). Oppilaan matematiikkakuva oppimistuloksena ja oppimisen taustatekijänä. Teoksessa J. Joutsenlahti, H. Silfverberg \& P. Räsänen (toim.), Matematiikan opetus ja oppiminen (ss. 132-155) . Jyväskylä: Niilo Mäki Instituutti. 


\section{Ainedidaktiikka 4(1) (2020)}

Hiltunen, J. \& Nissinen, K. (2018). Erinomaiset matematiikan osaajat. Teoksessa J. Rautopuro \& K. Juuti (toim.), PISA pintaa syvemmältä. PISA 2015 Suomen pääraportti. Kasvatusalan tutkimuksia 77 (ss. 213-234). Jyväskylä: Suomen kasvatustieteellinen seura

Hirvonen, K. (2012). Onko laskutaito laskussa? Matematiikan oppimistulokset peruskoulun päättövaiheessa 2011. Koulutuksen seurantaraportit 2012:4. Helsinki: Opetushallitus.

Hotulainen, R., Rimpelä, A., Hautamäki, J., Karvonen, S., Kinnunen, J. M., Kupiainen, S., Lindfors, P., Minkkinen, J., Pere, L., Thuneberg, H., Vainikainen, M-P. \& Wallenius, T. (2016). Osaaminen ja hyvinvointi yläkoulusta toiselle asteelle. Tutkimus metropolialueen nuorista. Tutkimuksia 398. Helsingin yliopisto. http://urn.fi/URN:ISBN:978-952-03-0347-1

Huisman, T. (2006). Luen, kirjoitan ja ratkaisen. Peruskoulun kolmasluokkalaisten oppimistulokset äidinkielessä ja kirjallisuudessa sekä matematiikassa. Oppimistulosten arviointi 7/2006. Helsinki: Opetushallitus.

Jakku-Sihvonen, R. (2013). Oppimistulosten arviointijärjestelmästä ja niiden kehittämishaasteista. Teoksessa A. Räisänen (toim.), Oppimisen arvioinnin kontekstit ja käytännöt. Raportit ja selvitykset 2013: 3 (ss. 13-36). Helsinki: Opetushallitus.

Jiang, Y., Song, J., Lee, M. \& Bong, M. (2014). Self-efficacy and achievement goals as motivational links between perceived contexts and achievement. Educational Psychology, 34(1), 92-117. https://doi.org/10.1080/01443410.2013.863831

Jokivuori, P. \& Hietala, R. 2007. Määrällisiä tarinoita: Monimuuttujamenetelmien käyttö ja hallinta. Helsinki: WSOY.

Keltikangas-Järvinen, L. (2007). Koulu sosiaalisen pääoman lisääjänä ja elinikäisen oppimisen kasvattajana psykologisten tutkimustulosten valossa. Teoksessa S. Alatupa, K. Karppinen, L. Keltikangas-Järvinen \& H. Savioja (toim.), Koulu, syrjäytyminen ja sosiaalinen pääoma. Löytyykö huono-osaisuuden syy koulusta vai oppilaasta? Sitran raportteja 75 (ss. 23-44). Helsinki: Sitra. Viitattu 23.11.2019. https://media.sitra.fi/2017/02/27172704/raportti75-2.pdf

Kupari, P. (2006). Student and school factors affecting Finnish mathematics achievement: results from 1999 data. Teoksessa S. J. Howie \& T. Plomp (toim.), Contexts of learning mathematics and science. Lessons learned from TIMSS (ss. 127-140). London: Routledge,

Kupari, P. \& Hiltunen, J. (2018). Matemaattiset taidot kansainvälisten arviointitutkimusten valossa. Teoksessa J. Joutsenlahti, H. Silfverberg \& P. Räsänen (toim.), Matematiikan opetus ja oppiminen (ss. 16-53). Porvoo: Niilo Mäki Instituutti.

Kupari, P. \& Nissinen, K. (2015). Matematiikan osaamisen taustatekijät. Teoksessa J. Välijärvi \& P. Kupari (toim.), Millä eväillä osaaminen uuteen nousuun? PISA 2012 tutkimustuloksia. Opetus- ja kulttuuriministeirön julkaisuja 2015: 6 (ss. 1027). Viitattu 23.11.2019 http://julkaisut.valtioneuvosto.fi/bitstream/handle/10024/75126/okm6.pdf

Kupari, P., Sulkunen, S., Vettenranta, J. \& Nissinen, K. (2012). Enemmän iloa oppimiseen. Neljännen luokan oppilaiden lukutaito sekä matematiikan ja luonnontieteiden osaaminen. Kansainväliset PIRLS- ja TIMSS-tutkimukset Suomessa. Jyväskylän yliopisto. http://urn.fi/URN:ISBN:978-951-39-5011-8

Kupari, P., Välijärvi, J., Andersson, L., Arffman, I., Nissinen, K., Puhakka, E. \& Vettenranta, J. (2013). PISA12. Ensituloksia. Opetus- ja kulttuuriministeriön julkaisuja 2013:20. Viitattu 23.11.2019. http://julkaisut.valtioneuvosto.fi/bitstream/handle/10024/75271/okm20.pdf

Kupiainen, S. (2016). Päättöarvosanojen ennustaminen. Teoksessa R. Hotulainen, A. Rimpelä, S. Karvonen, S. Kupiainen, P. Lindfors, J. M. Kinnunen, J. Minkkinen, M-P. Vainikainen \& T. Wallenius (toim.), Metropolialueen nuorten siirtyminen yläkoulusta toiselle asteelle. Osaaminen ja hyvinvointi (ss. 25-29). Helsinki: Valtioneuvoston selvitys ja tutkimustoiminnan julkaisusarja 27/2016.

Kuusela, J. (2006). Temaattisia näkökulmia perusopetuksen tasa-arvoon. Oppimistulosten arviointi 6/2006. Helsinki: Opetushallitus.

Laine, S. (2010). Lahjakkuuden ja erityisvahvuuksien tukeminen. Opetushallitus. Viitattu 23.11.2019. http://www.edukustannus.fi/site/assets/files/1/lahjakkuuden ja erityisvahvuuksien tukeminen.pdf 


\section{Ainedidaktiikka 4(1) (2020)}

Leikin, R. (2014). Giftedness and high ability in mathematics. Teoksessa S. Lerman (toim.), Encyclopedia of mathematics education (ss. 247-251) . Dordrecht: Springer Reference. https://doi.org/10.1007/978-94-007-4978-8_65

Linnanmäki, K. (2004). Minäkäsitys ja matematiikan oppiminen. Teoksessa P. Räsänen, P. Kupari, T. Ahonen \& P. Malinen (toim.), Matematiikka - Näkökulmia opettamiseen ja oppimiseen (ss. 241-254). Jyväskylä: Niilo Mäki Instituutti.

Marks, G. N, Cresswell, J. Ainley, J. (2006). Explaining socioeconomic inequalities in student achievement. The role of home and school factors. Educational Research and Evaluation, 12(2), 105-128. https://doi.org/10.1080/13803610600587040

Metsämuuronen, J. (2003). Tutkimuksen tekemisen perusteet ihmistieteissä. Jyväskylä: International Methelp Ky.

Metsämuuronen, J. (2009). Metodit arvioinnin apuna. Perusopetuksen oppimistulosarviointien ja -seurantojen menetelmäratkaisut Opetushallituksessa. Oppimistulosten arviointi 1/2009. Helsinki: Opetushallitus.

Metsämuuronen, J. (2013). Perusopetuksen matematiikan oppimistulosten pitkittäisarviointi vuosina 2005-2012. Koulutuksen seurantaraportit 2013:4. Helsinki: Opetushallitus.

Metsämuuronen, J. (2017). Oppia ikä kaikki-Matemaattinen osaaminen toisen asteen koulutuksen lopussa 2015. Kansallinen koulutuksen arviointikeskus. Julkaisut $1: 2017$.

Metsämuuronen, J. \& Salonen, V. (2017). Matemaattisen osaamisen piirteitä ammatillisen koulutuksen lopussa 2015 ja pitkän ajan muutoksia. Kansallinen koulutuksen arviointikeskus. Julkaisut 2:2017.

Metsämuuronen, J. \& Tuohilampi, L. (2017). Matemaattisen osaamisen piirteitä lukiokoulutuksen lopussa 2015. Kansallinen koulutuksen arviointikeskus. Julkaisut 3:2017.

Mullis, I. V. S. \& Martin, M. O. (toim.) (2013). TIMSS 2015 assessment frameworks. Chestnut Hill, MA: TIMSS \& PIRLS International Study Center, Boston College.

Niemi, E. K. (2008). Matematiikan oppimistulosten kansallinen arviointi 6. vuosiluokalla vuonna 2007. Helsinki: Opetushallitus.

Niemi, E. K. \& Metsämuuronen, J. (toim.) (2010). Miten matematiikan taidot kehittyvät? Matematiikan oppimistulokset peruskoulun viidennen vuosiluokan jälkeen vuonna 2008. Koulutuksen seurantaraportti 2010:2. Helsinki: Opetushallitus.

Nissinen, K. \& Vuorinen, R. (2018). Alueelliset erot luonnontieteiden osaamisessa ja niitä selittävät tekijät: oppilaanohjauksella on merkitystä. Teoksessa J. Rautopuro \& K. Juuti (toim.) PISA pintaa syvemmältä. PISA 2015 Suomen pääraportti. Kasvatusalan tutkimuksia 77 (ss. 69-96). Jyväskylä: Suomen kasvatustieteellinen seura,.

OECD (2013). PISA 2012 Assessment and analytical framework: mathematics, reading, science, problem solving and financial literacy. Paris: OECD Publishing. https://doi.org/10.1787/9789264190511-en

OECD (2018). Education at a Glance 2018: OECD Indicators. Paris: OECD Publishing. https://doi.org/10.1787/19991487

Opetushallitus (2004). Perusopetuksen opetussuunnitelman perusteet 2004. Helsinki: Opetushallitus.

Opetushallitus (2014). Perusopetuksen opetussuunnitelman perusteet 2014. Määräykset ja ohjeet 2014:96. Helsinki: Opetushallitus.

Pursiainen, J., Muukkonen, H., Rusanen, J. \& Harmoinen, S. (2018). Lukion ainevalinnat ja tasa-arvo. Oulun yliopisto. Viitattu 23.11.2019. http://jultika.oulu.fi/files/nbnfi-fe201803135965.pdf

Rautopuro, J. (toim.) (2013). Hyödyllinen pakkolasku. Matematiikan oppimistulokset peruskoulun päättövaiheessa 2012. Koulutuksen seurantaraportit 2013:3. Helsinki: Opetushallitus.

Renzulli, J. S. \& Reis, S. M. (1985). The Schoolwide enrichment model: A comprehensive plan for educational excellence. Mansfield Center, CT: Creative Learning Press.

Robitaille, D. F. \& Garden R. A. (toim.) (1996). TIMSS monograph No. 2: Research questions \& study design. Vancouver: Pacific Educational Press.

Ruokamo, H. (2000). Matemaattinen lahjakkuus ja matemaattisten sanallisten ongelmanratkaisutaitojen kehittäminen teknologiaperustaisessa oppimisympäristössä. Tutkimuksia 212. Helsingin yliopiston opettajankoulutuslaitos. Helsinki: Yliopistopaino. 


\section{Ainedidaktiikka 4(1) (2020)}

Räsänen, P., Närhi, V. \& Aunio P. (2010). Matematiikassa heikosti suoriutuvat oppilaat perusopetuksen 6. luokan alussa. Teoksessa E. K. Niemi \& J. Metsämuuronen (toim.), Miten matematiikan taidot kehittyvät? Matematiikan oppimistulokset peruskoulun viidennen vuosiluokan jälkeen vuonna 2008. Koulutuksen seurantaraportit 2010:2 (ss. 165-203). Helsinki: Opetushallitus.

Schunk, D. \& Richardson, K. (2011). Motivation and Self-Efficacy in Mathematics Education. Teoksessa D. J. Brahier \& W. R. Speer (toim.), Motivation and disposition: Pathways to learning mathematics. Reston, VA: The National Council of Teachers of Mathematics.

Sheffield, L. J. (1994). The Development of Gifted and Talented Mathematics Students and the National Council of Teachers Mathematics Standards. Northern Kentucky University. Highland Heights, Kentucky. Viitattu 23.11.2019. http://books.google.fi/books?hl=fi\&lr=\&id=osAfwTWy3X0C\&oi=fnd\&pg=R\&r edir $\mathrm{esc}=\mathrm{y} \# \mathrm{v}=$ onepage $\& \mathrm{q} \& \mathrm{f}=$ false

Snellman, L. \& Räty, H. (1998). Tunne älysi, käy koulua. Teoksessa A. Malin \& K. Männikkö (toim.), Älykkyys valoa ja varjoja (ss. 82-89). Jyväskylä: Atena Kustannus.

Tang, X., Wang, M-T., Guo, J. \& Salmela-Aro, K. (2019). Building Grit: The Longitudinal Pathways between Mindset, Commitment, Grit and Academic Outcomes. Journal of Youth and Adolescence, 48(5), 850-863. https://doi.org/10.1007/s10964-019-00998-0

Tuohilampi, L. \& Hannula, M. S. (2013). Matematiikkaan liittyvien asenteiden kehitys sekä asenteiden ja osaamisen välinen vuorovaikutus 3, 6. ja 9. luokalla. Teoksessa J. Metsämuuronen (toim.), Perusopetuksen matematiikan oppimistulosten pitkittäisarviointi vuosina 2005-2012. Koulutuksen seurantaraportit 2013:4 (ss. 231254). Opetushallitus: Helsinki.

Vettenranta, J, Hiltunen, J, Nissinen K, Puhakka, E. \& Rautopuro, J. (2016a). Lapsuudesta eväät oppimiseen. Neljännen luokan oppilaiden matematiikan ja luonnontieteiden osaaminen. Kansainvälinen TIMMS-tutkimus Suomessa. Jyväskylä: Jyväskylän yliopistopaino.

Vettenranta, J., Välijärvi, J., Ahonen, A., Hautamäki, J., Hiltunen, J., Leino, K., Lähteinen, S., Nissinen, K., Nissinen, V., Puhakka, E., Rautopuro, J., Vainikainen, M-P. (2016b). Huipulla pudotuksesta huolimatta. PISA 15 ensituloksia. Opetus- ja kulttuuriministeriön julkaisuja 2016:41. http://urn.fi/URN:ISBN:978-952-263-436-8

Välijärvi, J. (2017). PISA 2015: oppilaiden hyvinvointi. Jyväskylä: Koulutuksen tutkimuslaitos.

Williams, T. \& Williams, K. (2010). Self-efficacy and performance in mathematics: Reciprocal determinism in 33 nations. Journal of Educational Psychology, 102(2), 453-466. https://doi.org/10.1037/a0017271

Winheller, S., Hattie J. A. \& Brown, G. T. (2013). Factors influencing early adolescents' mathematics achievement: High-quality teaching rather than relationships. Learning Environments Research, 16(1), 46-69. https://doi.org/10.1007/s10984-012-9106-6 